Article

\title{
Physical and Hydro-Physical Characteristics of Soil in the Context of Climate Change. A Case Study in Danube River Basin, SE Romania
}

\author{
Sorina-Simona Moraru ${ }^{1}\left(\mathbb{D}\right.$, Antoaneta Ene ${ }^{2, *}$ (I) and Alina Badila ${ }^{3}$ \\ 1 Doctoral School of Mechanical and Industrial Engineering, Dunarea de Jos University of Galati, \\ 47 Domneasca Street, 800008 Galati, Romania; simoarb@yahoo.com \\ 2 INPOLDE Research Center, Faculty of Sciences and Environment, Department of Chemistry, \\ Physics and Environment, Dunarea de Jos University of Galati, 47 Domneasca Street, 800008 Galati, Romania \\ 3 Galati County Soil Survey Office, 26 Stiintei Street, 800146 Galati, Romania; simionica.alina@yahoo.com \\ * Correspondence: aene@ugal.ro
}

Received: 7 October 2020; Accepted: 2 November 2020; Published: 4 November 2020

\begin{abstract}
The intensification of climate change has led to the degradation of thousands of arable lands through desertification and extreme weather events. The Danube River basin in the Galati-Braila region, SE Romania, is a transboundary area of community and international importance, increasingly affected by drought, water, and wind erosion. Consequently, the aim of this study is to evaluate the main physical and hydro-physical parameters of soils, implied in water storage and with a defining role in erosion intensity, nutrients and toxicants cycle and availability, and crops yield. Soil samples were collected both in the disturbed and undisturbed state, from Smardan, Sendreni, and Vadeni agricultural lands and riparian areas of semiaquatic ecosystems, located in the vicinity of the steel platform of the Galati industrial area. Specific laboratory methods of investigation and formulas were used. Chernozems (CZ), Fluvisols (AS), and Gleysols (GS) of different subtypes and various physico-chemical parameters were identified. The results suggested that $\mathrm{CZ}$ are of coarse and medium texture, while AS and GS are medium-fine and fine textured. In correlation with this, bulk density values range from extremely low-low to low-high classes. In relation to soil physical parameters and the content of organic matter, hydro-physical indices show water supply imbalances. Through the approached theme, the study is of practical importance for sustainable management of the soil, agricultural projects, and landscaping. This study provides government authorities and non-governmental organizations an overview of the local and regional soil conditions, so that new measures can be regulated to protect it against irrational use.
\end{abstract}

Keywords: soil; drought; riparian lands; industrial areas; humidity; agroecosystem

\section{Introduction}

In the last century, climate change, with all its phenomena, has been intensified compared to the pre-industrial period and demographic explosion alike. Therefore, these changes have the consequence of endangering human health, food production, global economy, soil and water resources, and the balance of terrestrial and aquatic ecosystems [1-4]. One of the reasons for the worsening climatic conditions is attributed to anthropogenic activities (industry, mining, road traffic, intensive agriculture).

In recent years, the phenomenon of aridization has captured the attention of researchers, especially the impact it has on terrestrial ecosystems, and also on cultivated plants, as it is a significant one. Massive deforestations, having as their primary objective the change of the land use category for agricultural purposes, have put pressure on the environment, so we are currently confronted with major imbalances in natural ecosystems and agroecosystems. The average annual 
temperatures increased, and the precipitation amounts decreased considerably, registering appreciable regional variability. Adjacent to changes in temperature and rainfall, extreme weather events have intensified, causing disturbances in terrestrial and aquatic ecosystems and endangering human health [5]. Thousands of hectares of arable land worldwide are affected by drought and short-term torrential rains [6,7]. Prolonged periods of drought, followed by torrential rains, have the effect of destroying the soil structure and removing fertile layers, so that farmers are struggling to sustain productive crops. Lately, a very debated topic by researchers is that of tourism's impact on the environment. The connection between tourism activities, in all their forms, and infrastructure setting up, soil degradation, and associated risks, has already been shown [8-10], as well as changes in the soil parameters due to tourist traffic [11], such as increases in soil compaction and, consequently, low soil moisture and reduced water capacity. The studied area, part of the Lower Danube Euroregion in Romania (Galati-Braila-Tulcea), has a high tourist potential, due to the Roman vestiges (i.e., mounds, fortresses), paleontological reservations, museums, memorial houses, and old places of worship and natural heritage. The local authorities have studied the tourist potential of the area, but for the planning and implementation of a local/zonal tourism development program, in-depth impact studies on environment and population behavior are necessary $[12,13]$.

Soil, together with the other components of the environment, (e.g., rocks, water, and air), is a very important element for maintaining life on Earth, having a defining role in all the physical, chemical, and biological processes. The importance of soil in providing food for the Earth's population should not be treated superficially. It requires strict rules of protection, especially as it is an exhaustible resource, but fortunately, renewable under conditions of rational use. Globally, the soil provides about $98.8 \%$ of the Earth's food resources [14].

Climate change process intensification in the last century has led to soil degradation, amplification of nutrient deficiencies, or, vice versa, excesses in certain areas. Non-compliant irrigations have generated, in certain areas, the rise of the pedophreatic level and the installation of the secondary salinization phenomenon, causing deficiencies in the development of cultivated and natural vegetation alike. Keeping soil moisture for a longer period of time is one of the challenges of the modern world, all the more so as soil water scarcity has an overwhelming influence on agricultural production [15].

Water retention in soil is influenced by various factors, such as: Physical (soil texture, structure, compaction) and chemical (humus content, soluble salt concentration in soil solution) soil properties, or a series of ecological factors (temperature, distribution of rainfall over the year and their regime, intensity and frequency of winds, ground slope, vegetation type and distribution) [16]. Researches carried out by [17-19] highlighted the importance of assessing the physical characteristics of soils in order to establish their quality, in relation to the soil's ability to retain water, its texture, organic matter content, and micro and mesofauna activity. At the same time, it has been shown that, at least in the case of cultivated soils, the humidity in the agrochemical layer is closely related to the agrotechnical works applied to the preparation of the land for cultivation and during the vegetation period for the maintenance of the crops. Intensive land cultivation and diminishing of the amount of organic matter in upper soil horizons by complete release of vegetation after harvesting are the precursors of erosion phenomenon installation and intensification. Soil erosion may have one of the most serious impacts on soil quality and its productivity [20]. Moreover, erosion is a process that causes contamination of the environment with particles of sediment and pollutants (heavy metals, nutrients, pesticides, waste) transported by water runoff from the surface of the soil in the neighboring regions at lower altitudes and deposited on the banks and in the riverbeds [21,22]. In the case of pastures, the repeated movement of animals on the same surfaces, without respecting the grazing calendar and the rotation of the parcels for their feeding, leads to soil compaction, so that they store low amounts of water [23,24].

An important factor in characterizing a territory from a hydrological point of view is the climate, through the distribution of temperatures and precipitation throughout the year. The dynamics of nutrient circulation in the soil-plant relationship must be assessed according to soil properties and climatic factors. The physical properties of the soil are directly involved in the absorption and 
mobility of micro- and macronutrients, as well as toxic or potentially toxic elements and their transfer to plants $[25,26]$. Moreover, they are closely related to the hydro-physical parameters of the soil. Researches in the field have shown that in both dry and humid periods the variation in nutrients concentration in plants is related to the soil $\mathrm{pH}$, its granulometric composition, and the supply of soil with essential micro- and macro-elements involved in plant nutrition [27].

The role of the relief, which through its distribution and slope influence the regime of water in soil, is definitory. There is a close link between land slope, erosion degree, and physical properties of soils. Erosion affects the physical properties of the soils, but at the same time, low permeable compacted soils are more susceptible to erosion than those with higher water retention and a low degree of compaction $[28,29]$.

In the process of water penetration into the soil, the granulometric composition has, by far, a defining role, along with humus and other soil parameters. Among the particle fractions, those of $<0.002 \mathrm{~mm}$ size have the greatest influence on water storage and accessibility [30]. Therefore, soils with fine and fine-medium texture usually have a lower water permeability, while in soils with coarse textures, water penetrates more easily [31]. Many authors have shown that there is a close relationship between bulk density, the particle size of the soil, and the soil's organic matter content [32-34]. It was reported that the influence of organic matter on soil quality and the causal link between it and the state of soil structural aggregates, in relation to the concentration of soils organic matter, clay and silt fractions [35]. At the same time, a direct relationship between the soil organic matter content and type and the water infiltration rate was shown, depending also on some physical parameters of soil (bulk density, porosity, and percentage composition of particle size fractions) [36,37].

The content of organic matter plays an important role in the nutrients cycle, aggregates stabilization, and physical and hydro-physical properties positive changes [38]. Most of the time, the intensive and non-compliant agricultural practices with the climatic conditions and the soil properties lead, at a given moment, to significant changes in the concentration of the organic matter in the agricultural layer. Globally, measures are needed for the agroecosystems' conservation and protection and qualitative soil improvement, one of the best known being organic fertilization [39].

Considering the agricultural land use and the position of plots near the industrial platform of the steel plant from Galati, SE Romania, as well as wetlands and nature protected areas of Prut and Siret rivers, tributaries of the Danube River in the Black Sea basin, several studies have reported the presence of pollutants in the agricultural layer (heavy metals, organochlorine pesticides, polycyclic aromatic hydrocarbons) in different concentrations [40-43]. Additionally, recent studies in the same area [44,45] demonstrated the ability of some culture plants to bioaccumulate heavy metals, which induced a risk to human and animal health.

The process of transferring pollutants or potentially toxic elements to plants is related to all the physical and chemical properties of soils, under certain ecological conditions, which may slow down, block or accelerate bioaccumulation [46].

To the best of our knowledge, there is no study related to the complex assessment of soil parameters in semi-aquatic ecosystems of the lower sector of Danube basin. Previously published data are less correlated with soil's physical and chemical factors, which influence accumulation and bioavailability of toxicants from air, pesticides, mineral fertilizers, nutrients cycle, and soil moisture. In these conditions, the present study aims to investigate the main physical and hydro-physical properties of agricultural soils next to the industrial area, located in the Danube basin, involved in the availability and bioaccumulation of nutrients and toxic substances in the vegetative organs of crops. Herein the main hydro-physical characteristics of soils are evaluated in relation to texture, humus content, and bulk density. This study is part of a broader research of local and regional environmental and anthropogenic factors in the Danube river and Black Sea basins, and the obtained results will be correlated with the level of toxic and non-toxic elements identified in soil, sediments water, and biota, in order to evaluate the mode of their transfer between environmental compartments in specific conditions, the extent of pollution, nutritive deficiency, and ecological and health risks. 
The practical importance of this research is that it contributes to the awareness of stakeholders and policy makers on the importance of knowing all the characteristics of natural ecosystems and agroecosystems in a given area when deciding to start local/regional development projects, improving deficiencies, etc. According to European policies and mitigation programs related to climate change impact [47-49], national regulations require sustainable agricultural management, food security, and natural habitats monitoring. In this context, agro-pedological studies are the basis for substantiating projects for rehabilitation of degraded land surfaces and increasing crop production.

\section{Materials and Methods}

\subsection{Study Area}

The soil study was conducted in the south of Moldova province, Galati and Braila counties, covering the nearest agricultural area under the influence of the steel industry in SE Romania. The target region was selected due to the closeness of the area of influence of the steel plant in Galati and natural and transboundary areas of community and international importance for the Lower Danube Euroregion and Black Sea basin. Galati is the biggest port on the maritime Danube, located at the confluence of Danube with its main tributaries in the Lower Danube River basin, Siret and Prut Rivers [43]. The study area is located at about $15 \mathrm{~km}$ from Galati, between $45^{\circ} 42^{\prime} 18^{\prime \prime} \mathrm{N}$ latitude to $27^{\circ} 54^{\prime} 39^{\prime \prime}$ E longitude and $45^{\circ} 17^{\prime} 29^{\prime \prime} \mathrm{N}$ latitude to $27^{\circ} 50^{\prime} 45^{\prime \prime}$ E longitude, on Smardan and Sendreni territories (Galati county), and Vadeni territory (Braila county)—Figure 1. Galati and Braila counties are separated by the Siret River corridor, a tributary on the left side of the Danube River, which is a part of the "Natura 2000" European protected areas network. Riparian areas from NW of Vadeni and S of Sendreni communes overlap on Special Protection Area (SPA) 0071 and Site of Community Importance (SCI) 0162 of Lower Siret Meadow. The location of the soil profiles was established according to the local environmental factors, the distance from the industrial platform, and the general direction of the wind, as an important factor in the transmission of pollutants in the environment $[40,43]$.

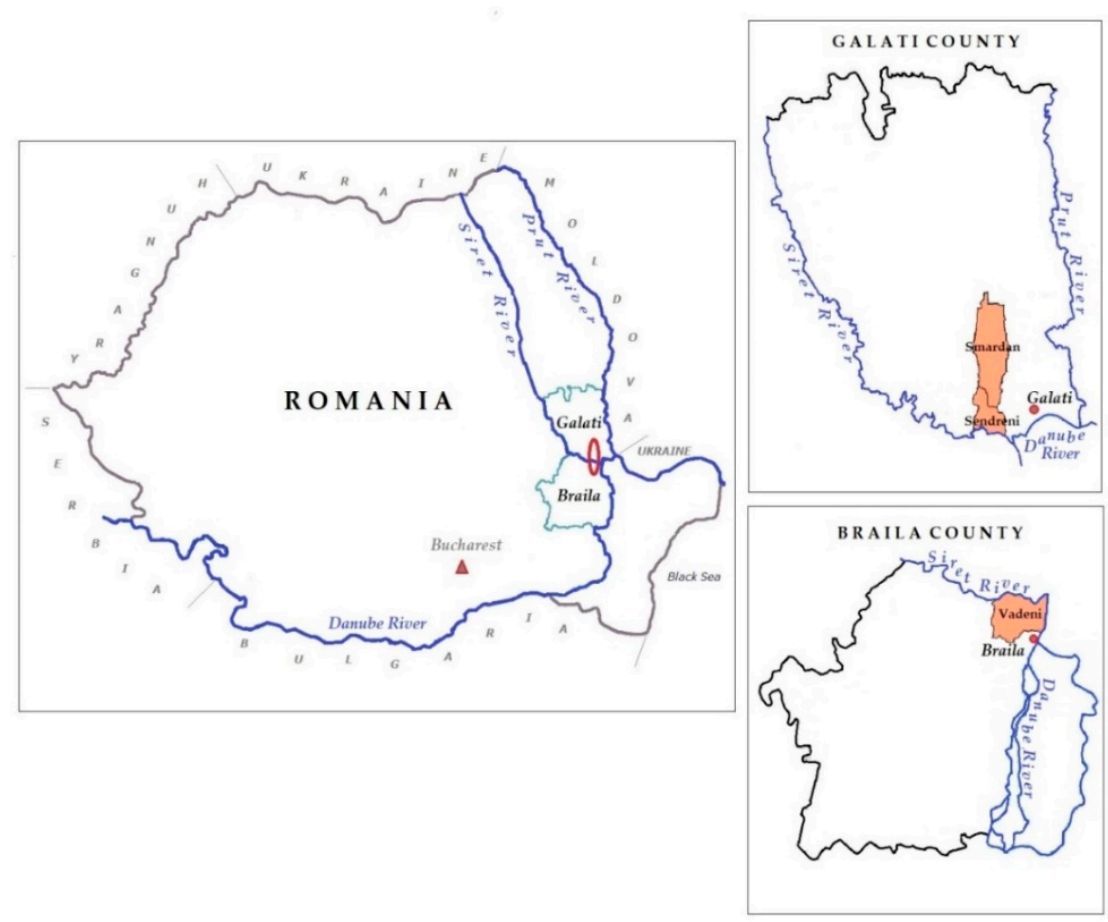

Figure 1. Map of the study area location in SE Romania. 


\subsection{Physical-Geographical Characterization of the Study Area}

The relief consists of two large units, the High Plain of Covurlui (southern Moldavian Plateau) —Smardan and Sendreni territories, and Braila Plain (northeast of the Romanian Plain) —Vadeni territory. They are separated by Siret Lower Plain, which represents a subsidence area, lower than the surrounding areas. The general slope of the relief is on the NNV-SSE direction, in accordance with that of the geological deposits, so that its altitude gradually decreases from north (142-163 m Piscul Fintanii Hill, north of Smardan commune) to the south, where in the Siret Lower Plain and Braila Plain has the lowest values (2-6 m). The hilly relief to the north of the Siret corridor is characterized mainly by the second type of structural asymmetry, the surface being fragmented by consequent valleys, which indicates the recent age of the relief. The slopes range from $1^{\circ}$ to $11^{\circ}$, and are affected by low-moderate erosion. At the south of Siret, the general land slope is of $<1-2^{\circ}$, unaffected by surface erosion.

\subsubsection{Geology}

The Smardan-Sendreni area overlaps the southern part of the Bârlad Depression, represented by the Covurlui Platform, characterized by strong tectonic sinking due to the subduction of the southern part of the Moldavian Platform, which borders to the north, and the North-Dobrogean Promontory, located at the southern limit of the depression [50]. The Vadeni territory is located on the Valah Depression [51]. The Covurlui Platform basement, defined by a block structure, is of Hercynian-Kimmeric North Dobrogea type and consists of crystalline schists of Precambrian age (gneiss, amphibolites, pierced by eruptive rocks) and Paleozoic, Triassic, and Liasic sediments (sandy conglomerates, limestone, dolomite, sandstone, clays, and sandy clays). The basement of the Moesic Platform is of late Proterozoic-early Paleozoic age and consists of crystalline schists with magmatic intrusions. The sedimentary cover, of Quaternary age, consists of loess layers and loessoid deposits of appreciable thicknesses in the Covurlui Plain. On interfluves, the quaternary deposits are of aeolian origin, and in the meadow area, they have fluvial origin. In this location, the soils were formed on the basis of parental materials represented by loess and loessoid deposits [50,51].

\subsubsection{Climate}

The researched area is part of the excessive temperate-continental climate, characterized by hot, dry summers and frosty winters. The average annual temperature varies from $10.7^{\circ} \mathrm{C}$ degrees in the north of Siret to $11{ }^{\circ} \mathrm{C}$ in the south of Siret. The average monthly temperatures show large oscillations during a year. The highest average temperature is recorded in July $\left(22.4^{\circ} \mathrm{C}\right.$, Galati station), and the lowest in January $\left(-25^{\circ} \mathrm{C}\right.$, Braila station). The average annual rainfall varies between $485.7 \mathrm{~mm}$ (Galati station) and $460.5 \mathrm{~mm}$ (Braila station). Precipitations are unevenly distributed throughout the year, most being heavy rainfall. The torrential character of the rains cumulated with the granulometric composition of the soils, the low content of organic matter, and agricultural practices lead to high annual soil losses.

The continental character of the climate is highlighted by the values of the De Martonne Aridity Index, which falls between 22 (Vadeni) and 23 (Sendreni and Smardan), the Hydro-climatic Index, which is 64 (Vadeni) and 70 (Sendreni and Smardan), respectively, and the Hydro-climatic Balance ranging between -205.3 (Sendreni and Smardan) and -254.5 (Vadeni), which places the studied area in a hydroclimatic deficient zone.

\subsubsection{Hydrography}

The hydrographic network is a tributary to the Danube, the studied surface being drained by a series of affluents of the Siret river. They have a temporary course and high alluvial transport capacity during heavy rainfall. Overall, the groundwater can be intercepted at depths over $10 \mathrm{~m}$, on the interfluves of the Covurlui Plain, and at $2-5 \mathrm{~m}$ in the riparian areas. On interfluves, the groundwater 
does not influence the pedogenesis process, unlike the meadow area where vertical oscillations take place during the year, resulting in the installation of oxidation-reduction and salinization phenomena.

\subsubsection{Vegetation}

From a floristic viewpoint, the researched region falls within the steppe area, represented by xerophilous species [52]. The natural vegetation is still preserved on small areas, along the irrigation canals, on natural meadows, and on uncultivated lands. In the Siret and Danube meadows, as well as along the small tributaries, the vegetation is made up of hydro-mesophilic species.

\subsection{Soil Mapping}

Twelve soil profiles were executed on each of the three above mentioned territories, and a total of twenty-four samples from the first two genetic horizons, up to about $50 \mathrm{~cm}$ depth, were taken. The profiles were labeled as follows: 1, 2, 3, 4 (Smardan), 5, 6, 7, 8 (Sendreni), 13, 14, 15, 16 (Vadeni).

At the same time, eight soil samples were harvested, on 0-30 cm agricultural depth, four from the Sendreni territory (noted 9, 10, 11, 12) and four from the Vadeni territory (noted 17, 18, 19, 20), respectively. Sampling points location may be seen in Figure 2a-c.

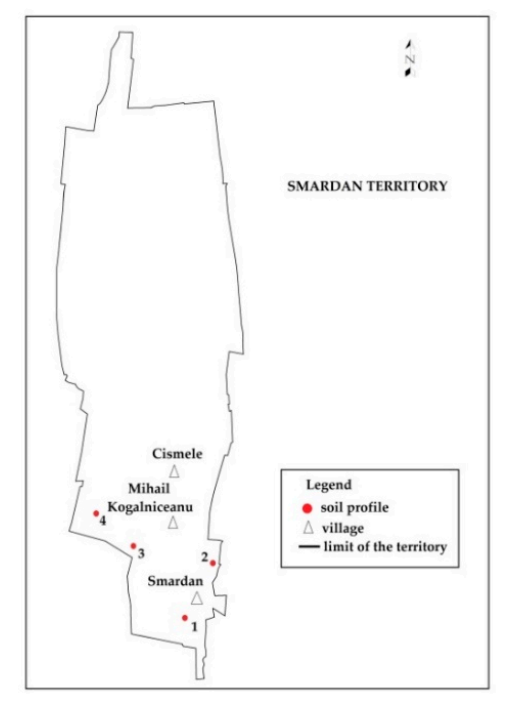

(a)

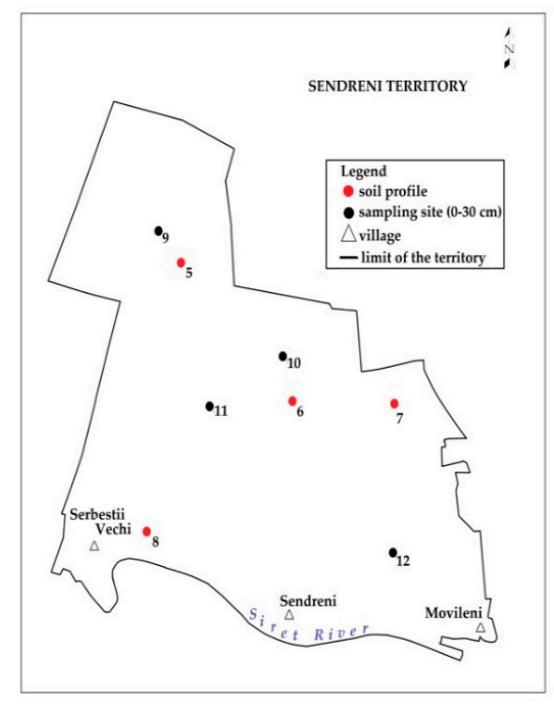

(b)

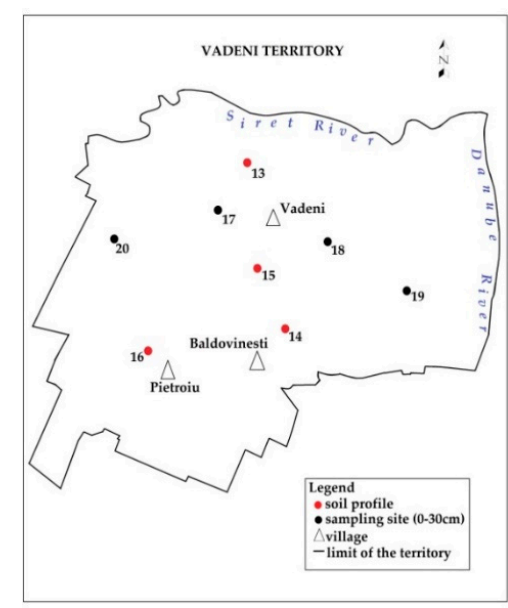

(c)

Figure 2. Sampling points location, (a) Smardan, (b) Sendreni, and (c) Vadeni territories. 
Field research was performed in the summer season (July, August) and early autumn (September) of 2014, 2017, 2018, and 2019. Soil types and subtypes were taxonomically classified according to the Romanian System of Soil Taxonomy [53], on the basis of genetic horizons. The samples were taken with a hard-plastic spatula, from bottom to top, and stored in labeled bags until their analysis. For bulk density (BD) investigation, soil was harvested in 3 metallic cylinders of known volume $\left(200 \mathrm{~cm}^{3}\right)$, as in Figure 3b,c, by Cylindrical core method. The profiles and additional samples pits were performed on different land use categories, on arable land, and on pastures, located on different classes of slopes and orientation. The coordinates of the sampling points, shown in Table 1, were recorded with a Magellan portable GPS model 980616-01 (Figure 3a). Site positions were reported to the WGS-84 ellipsoid, and the altitudes were recorded according to the ellipsoidal height system.

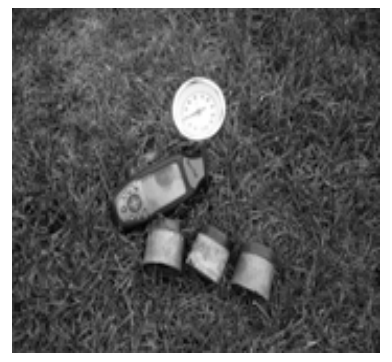

(a)

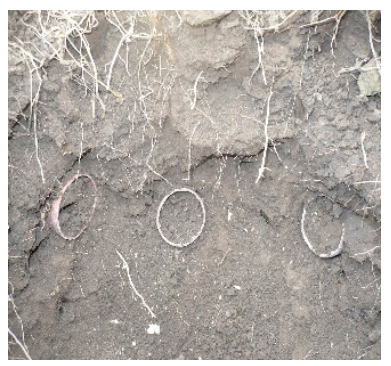

(b)

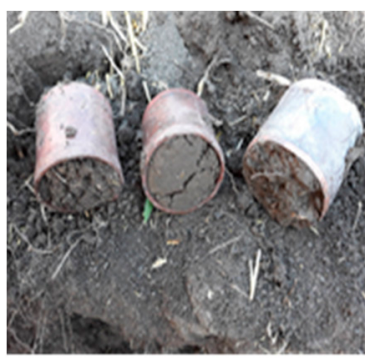

(c)

Figure 3. (a) Tools and equipment used for specific determinations (soil thermometer, GPS, cylinder); $(\mathbf{b}, \mathbf{c})$ Metallic cylinders for bulk density filled with soil.

Table 1. Sampling points position: Soil profiles (a); additional sampling (b).

\begin{tabular}{|c|c|c|c|c|c|}
\hline Sample Site & Location & Latitude $\mathbf{N}$ & Longitude E & Altitude (m) & Slope \\
\hline \multicolumn{6}{|c|}{ Smardan } \\
\hline 1 & S Smardan & $45^{\circ} 27^{\prime} 58.20^{\prime \prime}$ & $27^{\circ} 56^{\prime} 10.70^{\prime \prime}$ & 18 & $2-5^{\circ}$ \\
\hline 2 & NE Smardan & $45^{\circ} 29^{\prime} 1.68^{\prime \prime}$ & $27^{\circ} 57^{\prime} 8.58^{\prime \prime}$ & 41 & $11-14^{\circ}$ \\
\hline 3 & SW M. Kogalniceanu & $45^{\circ} 29^{\prime} 29.14^{\prime \prime}$ & $27^{\circ} 54^{\prime} 44.62^{\prime \prime}$ & 80 & $\leq 1^{\circ}$ \\
\hline 4 & W M. Kogalniceanu & $45^{\circ} 30^{\prime} 14.69^{\prime \prime}$ & $27^{\circ} 53^{\prime} 37.84^{\prime \prime}$ & 83 & $1-2^{\circ}$ \\
\hline \multicolumn{6}{|c|}{ Sendreni } \\
\hline 5 & Trajan's Wall arable land & $45^{\circ} 27^{\prime} 55.38^{\prime \prime}$ & $27^{\circ} 53^{\prime} 50.96^{\prime \prime}$ & 68 & $\leq 1^{\circ}$ \\
\hline 6 & W Cornet Valley & $45^{\circ} 26^{\prime} 35.37^{\prime \prime}$ & $27^{\circ} 55^{\prime} 28.44^{\prime \prime}$ & 58 & $\leq 1^{\circ}$ \\
\hline 7 & E Malina Lake & $45^{\circ} 26^{\prime} 26.79^{\prime \prime}$ & $27^{\circ} 56^{\prime} 54.43^{\prime \prime}$ & 39 & $2-5^{\circ}$ \\
\hline 8 & left of Siret river & $45^{\circ} 25^{\prime} 23.50^{\prime \prime}$ & $27^{\circ} 53^{\prime} 22.85^{\prime \prime}$ & 39 & $2-5^{\circ}$ \\
\hline 9 & left of Odabascu Valley & $45^{\circ} 28^{\prime} 22.05^{\prime \prime}$ & $27^{\circ} 53^{\prime} 28.23^{\prime \prime}$ & 72 & $\leq 1^{\circ}$ \\
\hline 10 & right of Cornet Valley & $45^{\circ} 26^{\prime} 54.89^{\prime \prime}$ & $27^{\circ} 55^{\prime} 23.43^{\prime \prime}$ & 60 & $\leq 1^{\circ}$ \\
\hline 11 & right of Rusca Mare Valley & $45^{\circ} 26^{\prime} 37.00^{\prime \prime}$ & $27^{\circ} 53^{\prime} 59.00^{\prime \prime}$ & 58 & $1-2^{\circ}$ \\
\hline 12 & right of Malina Valley & $45^{\circ} 25^{\prime} 5.00^{\prime \prime}$ & $27^{\circ} 56^{\prime} 36.00^{\prime \prime}$ & 21 & $2-5^{\circ}$ \\
\hline \multicolumn{6}{|c|}{ Vadeni } \\
\hline 13 & right of Pislaru Valley & $45^{\circ} 19^{\prime} 37.15^{\prime \prime}$ & $27^{\circ} 55^{\prime} 49.39^{\prime \prime}$ & 5 & $\leq 1^{\circ} 01^{\prime}$ \\
\hline 14 & N Baldovinesti Village & $45^{\circ} 27^{\prime} 58.20^{\prime \prime}$ & $27^{\circ} 56^{\prime} 10.70^{\prime \prime}$ & 5 & $\leq 1^{\circ} 01^{\prime}$ \\
\hline 15 & S Vadeni Village & $45^{\circ} 20^{\prime} 51.62^{\prime \prime}$ & $27^{\circ} 55^{\prime} 5.93^{\prime \prime}$ & 3 & $\leq 1^{\circ} 01^{\prime}$ \\
\hline 16 & W Pietroiu Village & $45^{\circ} 19^{\prime} 23.10^{\prime \prime}$ & $27^{\circ} 52^{\prime} 9.17^{\prime \prime}$ & 7 & $\leq 1^{\circ} 01^{\prime}$ \\
\hline 17 & NW Vadeni Village & $45^{\circ} 22^{\prime} 43.00^{\prime \prime}$ & $27^{\circ} 54^{\prime} 40.00^{\prime \prime}$ & 5 & $\leq 1^{\circ} 01^{\prime}$ \\
\hline 18 & S Vadeni Village & $45^{\circ} 21^{\prime} 37.00^{\prime \prime}$ & $27^{\circ} 56^{\prime} 25.00^{\prime \prime}$ & 4 & $\leq 1^{\circ} 01^{\prime}$ \\
\hline 19 & left of Danube river & $45^{\circ} 20^{\prime} 15.89^{\prime \prime}$ & $27^{\circ} 58^{\prime} 46.09^{\prime \prime}$ & 3 & $\leq 1^{\circ} 01^{\prime}$ \\
\hline 20 & right of Zagna backwater & $45^{\circ} 21^{\prime} 38.99^{\prime \prime}$ & $27^{\circ} 51^{\prime} 32.26^{\prime \prime}$ & 5 & $\leq 1^{\circ} 01^{\prime}$ \\
\hline
\end{tabular}




\subsection{Soil Pre-Treatment and Analysis}

Soil samples were conditioned and analyzed in the laboratory of the County Soil Survey Office (CSSO) of Galati, according to the Romanian and international protocols. The following methods have been applied: Core cylinder method for bulk density. $\mathrm{BD}\left(\mathrm{g} \cdot \mathrm{cm}^{-3}\right)$ results were obtained by reporting the dry soil mass to the cylinder volume with which the sample was taken; the volumetric method for humus content according to the Romanian standard STAS 7184/21-82; the gravimetric method for granulometric analysis, after STAS 7184/10-79. The textural soil classes and subclasses were defined after textural classification and triangular diagram of texture according to [53]. We also used the information from CSSO Galati and Braila for Sendreni [54], Smardan [55], and Vadeni [56].

Physical and hydro-physical indicators of soils were determined by calculations based on bulk density, clay and silt percentage, and humus content, using specific formulas and classifications provided by $[57,58]$. The following were calculated: Physical indicators-total porosity (TP), aeration porosity (AP), compaction rate (CR), and hydro-physical characteristics-wilting coefficient (WC), field water capacity (FWC), useful water capacity (UWC), total capacity (TC), easily accessible water capacity (EAWC), and draining capacity (DC).

\subsubsection{Physical Parameters}

$\mathrm{TP}(\%, v / v)$ was calculated according to the following formula [57]:

$$
\mathrm{TP}=100 \cdot(1-\mathrm{BD} / \mathrm{D})
$$

where BD is bulk density $\left(\mathrm{g} \cdot \mathrm{cm}^{-3}\right)$ and D is soil density $\left(\mathrm{g} \cdot \mathrm{cm}^{-3}\right)$.

TP classes are correlated with soil layers texture as follows: Sandy texture $-<34-$ very low, 34-38-low, 39-43-medium, 44-48-high, 49-53-very high, >54-extremely high; loamy sandy texture-<36-very low, 36-40-low, 41-45-medium, 46-50-high, 51-55-very high, $>56$ - extremely high; sandy loamy texture-<37-very low, 37-41-low, 42-46-medium, 47-51-high, 52-56-very high, $>57$ - extremely high; loamy texture-<39-very low, 39-43-low, 44-48-medium, 49-53-high, 54-58-very high, $>59$ - extremely high; loamy clay texture-<42-very low, 42-46-low, 47-51-medium, 52-56- high, 57-61-very high, >62 — extremely high; clay texture-<46-very low, 46-50-low, 51-55-medium, 56-60-high, 61-65-very high, >66-extremely high.

An indicator used to evaluate the proportion of pores occupied by air is $\mathrm{AP}(\%, v / v)$, considering soil water content at field water capacity [56]. It was calculated using the formula:

$$
\mathrm{AP}=\mathrm{TP}-\mathrm{FWC} \cdot \mathrm{BD},
$$

where TP is total porosity $(\% v / v)$, FWC is field water capacity $(\% w / w)$, BD is bulk density $\left(\mathrm{g} \cdot \mathrm{cm}^{3}\right)$. AP classes are: <6-extremely low, 6-10-very low, 11-15-low, 16-22-medium, 23-30-high, $\geq 31$ - very high.

Soil compaction was appreciated depending on the values obtained for CR $(\%, v / v)$, calculated according to the formula [57]:

$$
\mathrm{CR}=[(\mathrm{MNP}-\mathrm{TP}) / \mathrm{MNP}] 100,
$$

where MNP is minim necessary porosity, established on the basis of the following calculation: $\mathrm{MNP}=45+0.163 \cdot \mathrm{C}$ (where $\mathrm{C}$ is the $<0.002 \mathrm{~mm}$ clay content, $\% w / w$ ). CR classes are as follows [58]: $\leq-19$-very loosened, from -18 to -11 -loosened, from -10 to 0 -non-compacted, from 1 to 10-slightly compacted, from 11 to 18 -moderately compacted, $>19$ —strongly compacted. 


\subsubsection{Hydro-Physical Parameters}

Soil hydro-physical parameters related to vegetation water needs and its accessibility for plants were estimated using the formulas below $[57,58]$. The following equations were used:

$$
\mathrm{WC}=0.05+0.35 \cdot \mathrm{C},
$$

where the WC $(\%, w / w)$ classes are: $<4$-very low, 4.1-8.0—low, 8.1-12.0-medium, 12.1-16.0—high, 16.1-25.0—very high, $>25.1$ —extremely high.

$$
\begin{gathered}
\text { FWC }=\left\{2.65+1.105 \cdot \mathrm{C}-0.0189 \cdot \mathrm{C}^{2}+0.0001678 \cdot \mathrm{C}^{3}+15.12 \cdot \mathrm{BD}-6.745 \cdot \mathrm{BD}^{2}-\right. \\
\left.0.1975 \cdot \mathrm{C} \cdot \mathrm{BD}+0.1 \cdot\left[\mathrm{S}-\left(2+1.1 \cdot \mathrm{C}-0.012 \cdot \mathrm{C}^{2}\right)\right]\right\} \cdot\left(1.13-0.002966 \cdot \mathrm{LD}+0.00000883 \cdot \mathrm{LD}^{2}\right)
\end{gathered}
$$

where C—clay $(<0.002 \mathrm{~mm}, \%)$, BD—bulk density $\left(\mathrm{g} \cdot \mathrm{cm}^{3}\right)$, S—silt $(\%)$, LD—soil layer depth $(\mathrm{cm})$.

Soil water content classes according to FWC $(\%, w / w)$ are [58]: <10-very low, 10-20-low, 21-25-medium, 26-30—high, 31-40—very high, $\geq 41$ —extremely high.

$$
\mathrm{UWC}=\mathrm{FWC}-\mathrm{WC}
$$

For agricultural soils, UWC $(\%, w / w)$ is appreciated as follows [58]: <4-very low, 4.1-8.0-low, 8.1-12—medium, 12.1-16.0—high, 16.1-25.0—very high, $>25.1$ - extremely high.

$$
\mathrm{TC}=\mathrm{TP} / \mathrm{BD}
$$

where the TC $(\%, w / w)$ classes are [58]: $\leq 20$-very low, 21-25-low, 26-30-medium, 31-40—high, 41-60—very high, $>60$ — extremely high.

$$
\mathrm{DC}=\mathrm{TC}-\mathrm{FWC}
$$

where the DC $(\%, \mathrm{~mm})$ is classified as [58]: <4-extremely low, 4-6-very low, 7-10-low, 11-15-medium, 16-22-high, >22-very high.

$$
\text { EAWC }=(1-\mathrm{n})(\mathrm{FWC}-\mathrm{WC}) \cdot \mathrm{H} \cdot \mathrm{BD} \cdot((100-\mathrm{Q}) / 100)
$$

where $\mathrm{H}$ - the thickness of the soil layer accessible to the roots $(\mathrm{cm}), \mathrm{Q}$-particle $>2 \mathrm{~mm}$ diameter, $\mathrm{n}$-accessible moisture fraction: $1 / 2$ for loamy and sandy loam soils; $2 / 3$ for sandy, sandy loam strongly compacted soils, clay loam moderately and strongly compacted soils, clay soils; $3 / 5$ for sandy loam slightly and moderately compacted soils and clay loam non-compacted or slightly compacted soils. The results are expressed in $\mathrm{m}^{3} \cdot \mathrm{ha}^{-1}$. Ref. [57] provided six classes of EAWC: $<300$-very low, 301-500—low, 501-700—medium, 701-900—high, 901-1200—very high, >1200—extremely high.

\section{Results and Discussion}

\subsection{Soil Types and Subtypes}

The investigated soils fall into three soil classes: Protisols, Cernisols, and Hydrisols [54,57]. From Protisols class were identified Fluvisols (AS), separated into the following subtypes: Calcaric mollic (ka mo), calcaric mollic gleyc (ka mo gc), and gleyc salic sodic ( $\mathrm{gc} \mathrm{sc} \mathrm{ac}$ ). They are located in the Siret meadow (Vadeni). The soils sequence of horizons is the following: AmCk, Am-CkGox-CkGr, Ao-CkGox-CkGrscac. In connection with the oscillations of the groundwater level, they have oxidative properties (Gox) under the first $22-24 \mathrm{~cm}$.

From the Cernisols class, the Chernozems (CZ) were identified with the typical (ti) and calcaric (ka) subtypes. They occupy the largest area of the studied territory. From a morphological viewpoint, they consist of the following succession of horizons: Am-AC-Ck. 
The low spread in this region is the Gleysols (GS), calcaric mollic (ka mo) subtype, from Hydrisols class. They are located in the vicinity of Vadeni village, a lower area with low drainage, which is why the reduction properties (Gr) appear in the first $50 \mathrm{~cm}$ of the soil. The succession of their horizons is: Amp-CkGox-CkGr.

The surface of mineral horizons is disturbed by plowing or other specific agrotechnical works (Amp, ACp, Aop), up to a depth of about $25 \mathrm{~cm}$. The upper horizons of the soils on the pastures are usually crossed by a dense network of roots, but on the Smardan territory (profile 2), due to the overgrazing, they are very thin and rare.

\subsection{Soil Physico-Chemical Properties}

\subsubsection{Soil Organic Matter Content}

Organic matter $(\mathrm{OM})$ concentration in soil influences its physico-chemical properties, being both a binder of particles and a permanent source of nutrients for plants [35,37].

Table 2 shows the OM content in surface layers of soil. Generally, investigated soils are from very low to moderately supplied with OM. There is a gradual decrease of concentration from the surface to the lower soil's horizons.

Table 2. Organic matter (OM) content in surface layers.

\begin{tabular}{|c|c|c|c|c|}
\hline Sample Site & Horizon & Depth $(\mathrm{cm})$ & OM (\%) & Classes \\
\hline \multicolumn{5}{|c|}{ Smardan } \\
\hline \multirow{2}{*}{1} & Amp & $0-15$ & 2.45 & medium \\
\hline & $\mathrm{AC}$ & $15-55$ & 1.52 & low \\
\hline \multirow{2}{*}{2} & Amt & 0-19 & 3.16 & low \\
\hline & $\mathrm{AC}$ & $19-55$ & 1.91 & low \\
\hline \multirow{2}{*}{3} & Amp & $0-33$ & 1.48 & low \\
\hline & $\mathrm{AC}$ & $33-65$ & 1.17 & very low \\
\hline \multirow{2}{*}{4} & Amp & $0-21$ & 1.36 & low \\
\hline & $\mathrm{AC}$ & $21-48$ & 0.79 & very low \\
\hline \multicolumn{5}{|c|}{ Sendreni } \\
\hline \multirow{2}{*}{5} & Amp & $0-21$ & 3.33 & medium \\
\hline & Am & $21-30$ & 3.40 & medium \\
\hline \multirow[b]{2}{*}{6} & Amp & $0-25$ & 2.95 & low \\
\hline & Am & $25-40$ & 2.46 & low \\
\hline \multirow{2}{*}{7} & Amp & $0-14$ & 2.51 & low \\
\hline & Am & $14-29$ & 2.67 & low \\
\hline \multirow{2}{*}{8} & $\mathrm{ACp}$ & $0-22$ & 2.49 & low \\
\hline & $\mathrm{Ck}$ & $22-59$ & 1.22 & very low \\
\hline 9 & Amp/Am & $0-30$ & 3.03 & low \\
\hline 10 & Amp/ACk & $0-30$ & 2.53 & low \\
\hline 11 & Amp/ACk & $0-30$ & 1.59 & low \\
\hline \multirow[t]{2}{*}{12} & Amp/Am & $0-30$ & 1.19 & medium \\
\hline & & Vadeni & & \\
\hline \multirow{2}{*}{13} & Amp & $0-24$ & 3.04 & low \\
\hline & $\mathrm{Ck}$ & $24-51$ & 1.80 & very low \\
\hline \multirow{2}{*}{14} & Amp & $0-22$ & 2.88 & low \\
\hline & CkGox & $22-50$ & 2.07 & very low \\
\hline \multirow{2}{*}{15} & Amp & $0-23$ & 4.17 & low \\
\hline & CkGox & $23-50$ & 3.56 & low \\
\hline \multirow[b]{2}{*}{16} & Aop & $0-22$ & 2.21 & low \\
\hline & CkGox & $22-50$ & 1.14 & very low \\
\hline 17 & Aop/Ck & $0-30$ & 1.31 & very low \\
\hline 18 & $\mathrm{Amp} / \mathrm{CkGr}$ & $0-30$ & 2.37 & low \\
\hline 19 & Amp/CkGox & $0-30$ & 1.92 & low \\
\hline 20 & $\mathrm{Amp} / \mathrm{CkGr}$ & $0-30$ & 2.97 & low \\
\hline
\end{tabular}

The level of OM accumulation in the soil is related to its particle size composition. Usually, humus is more difficult to accumulate in sandy soils, given that coarse textural class is characterized by a slow development of bioaccumulation processes. At the opposite pole are clay soils, which tend to 
be better supplied with OM, even up to four times more than sandy ones, being better structured [59]. However, due to intensive agricultural practices combined with geographical factors, the soils of the three studied territories are affected in terms of OM accumulation. On Smardan territory, the mineral horizon Am has a humus concentration that falls within the limits of $1.36-3.16 \%$, while on the intermediate horizon AC, it has concentrations of $0.79-1.91 \%$.

Analytical results of Sendreni soils show that OM content ranges between $2.49-3.33 \%$ in the surface horizons Amp and ACp, tilled, and 1.22-3.40\% in the underlying horizons Am and Ck. In the layer $0-30 \mathrm{~cm}$, OM ranges between $0.85-3.03 \%$. Vadeni soils show a very low to low content of humus, related to its clayey texture. The concentrations are of $2.21-4.17 \%$ in Am and Ao layers, while in C horizon are between $1.14-3.56 \%$. In 0-30 cm soil layer OM values ranges between $1.31-2.97 \%$.

\subsubsection{Soil Granulometric Composition}

In addition, for soils' physical properties characterization, the granulometric composition was determined. This physical parameter is widely used to investigate the influence it has on the processes of bioaccumulation and biotransfer, as well as on the aspects of structural aggregates, the soil compaction rate, and water capacity [34,60]. Soil granulometric composition is shown in Table 3 [61], and percentage distribution by depths is presented in Figure $4 a-c$.

Table 3. Physical parameters of investigated soils.

\begin{tabular}{|c|c|c|c|c|c|c|c|c|}
\hline Sample Site & $\begin{array}{c}\text { Soil Type } \\
\text { [53] }\end{array}$ & Horizon & $\begin{array}{l}\text { Depth } \\
\text { (cm) }\end{array}$ & Clay (\%) & Silt (\%) & $\begin{array}{c}\text { FineSand } \\
(\%)\end{array}$ & $\begin{array}{c}\text { CoarseSand } \\
(\%)\end{array}$ & $\begin{array}{c}\text { Texture } \\
{[61]^{*}}\end{array}$ \\
\hline \multicolumn{9}{|c|}{ Smardan } \\
\hline \multirow{2}{*}{1} & \multirow[b]{2}{*}{ CZ ka } & Amp & $0-15$ & 15.18 & 23.56 & 57.63 & 3.63 & SM \\
\hline & & $\mathrm{AC}^{1}$ & $1-55$ & 9.34 & 24.47 & 63.82 & 2.37 & UF \\
\hline \multirow{2}{*}{2} & \multirow{2}{*}{ CZ ka } & Amt & 0-19 & 40.13 & 34.32 & 23.85 & 1.70 & $\mathrm{TP}$ \\
\hline & & $\mathrm{AC}$ & $19-55$ & 41.43 & 26.95 & 30.05 & 1.57 & TT \\
\hline \multirow{2}{*}{3} & \multirow[b]{2}{*}{ CZ ka } & Am & $0-33$ & 19.97 & 32.79 & 46.78 & 0.46 & SE \\
\hline & & $\mathrm{AC}$ & $33-65$ & 15.61 & 35.91 & 47.65 & 0.83 & SE \\
\hline \multirow{2}{*}{4} & \multirow{2}{*}{ CZ ka } & Amp & $0-21$ & 6.72 & 32.39 & 60.44 & 0.47 & UF \\
\hline & & $\mathrm{AC}$ & $21-48$ & 7.08 & 31.83 & 60.86 & 0.23 & UF \\
\hline \multicolumn{9}{|c|}{ Sendreni } \\
\hline \multirow{2}{*}{5} & \multirow{2}{*}{ CZ ka } & Amp & $0-21$ & 29.90 & 24.80 & 45.23 & 0.07 & LL \\
\hline & & $\mathrm{Am}$ & $21-30$ & 29.30 & 25.40 & 45.21 & 0.09 & LL \\
\hline \multirow{2}{*}{6} & \multirow{2}{*}{$\mathrm{CZ} \mathrm{ti}$} & Amp & $0-25$ & 30.83 & 26.42 & 42.67 & 0.08 & LL \\
\hline & & Am & $25-40$ & 32.84 & 26.41 & 40.59 & 0.16 & LL \\
\hline \multirow{2}{*}{7} & \multirow{2}{*}{ CZ ka } & Amp & $0-20$ & 27.01 & 25.35 & 47.26 & 0.38 & LL \\
\hline & & Am & $20-35$ & 26.37 & 26.16 & 47.11 & 0.36 & LL \\
\hline \multirow{2}{*}{8} & \multirow{2}{*}{ CZ ka } & $\mathrm{ACp}$ & $0-22$ & 23.04 & 29.31 & 47.41 & 0.24 & LL \\
\hline & & $\mathrm{Ck}$ & $22-59$ & 23.16 & 24.20 & 52.58 & 0.06 & LL \\
\hline 9 & CZ ka & Amp/Am & $0-30$ & 29.41 & 27.91 & 42.68 & 0.21 & LL \\
\hline 10 & CZ ka & Amp/ACk & $0-30$ & 28.30 & 30.20 & 41.50 & 0.17 & LL \\
\hline 11 & CZ ka & Amp/ACk & $0-30$ & 7.31 & 35.12 & 57.57 & 0.36 & $\mathrm{PN}$ \\
\hline 12 & CZ ka & Amp/Am & $0-30$ & 1.04 & 21.17 & 77.78 & 0.42 & NF \\
\hline \multicolumn{9}{|c|}{ Vadeni } \\
\hline \multirow{2}{*}{13} & \multirow{2}{*}{ AS ka mo } & Amp & $0-24$ & 53.41 & 34.16 & 12.08 & 0.35 & AP \\
\hline & & $\mathrm{Ck}$ & $24-51$ & 48.54 & 36.08 & 15.34 & 0.04 & $\mathrm{AP}$ \\
\hline \multirow{2}{*}{14} & AS ka mo & Amp & $0-22$ & 54.11 & 35.99 & 9.72 & 0.18 & AP \\
\hline & gc & CkGox & $22-50$ & 49.84 & 39.11 & 10.78 & 0.26 & AP \\
\hline \multirow{2}{*}{15} & \multirow{2}{*}{ GS ka mo } & Amp & $0-23$ & 65.91 & 25.78 & 8.17 & 0.14 & $\mathrm{AM}$ \\
\hline & & CkGox & $23-39$ & 63.18 & 25.99 & 10.64 & 0.19 & $\mathrm{AM}$ \\
\hline \multirow{2}{*}{16} & \multirow{2}{*}{ AS gc sc ac } & Aop & $0-22$ & 18.68 & 25.99 & 55.16 & 0.17 & SF \\
\hline & & CkGox & $22-50$ & 14.76 & 22.44 & 62.68 & 0.12 & SF \\
\hline 17 & AS ka & Aop/Ck & $0-30$ & 21.32 & 20.06 & 58.62 & 0.83 & LL \\
\hline 18 & GS ka mo & Amp/CkGr & $0-30$ & 27.79 & 25.60 & 46.62 & 1.13 & LP \\
\hline 19 & GS ka mo & Amp/CkGox & $0-30$ & 36.03 & 40.79 & 23.19 & 0.08 & TP \\
\hline 20 & GS ka mo & Amp/CkGr & $0-30$ & 41.03 & 37.30 & 21.66 & 0.08 & ТР \\
\hline
\end{tabular}

* NF-fine sand, UF-fine loamy sand, PN—sandy silt, SM-medium sandy loam, SF-fine sandy loam, SE—extra-fine sandy loam, LL—-medium loam, LP—silty loam, TT—medium clay loam, TP—silty clay loam, $\mathrm{AP}$ - silty clay, AM-medium clay. 


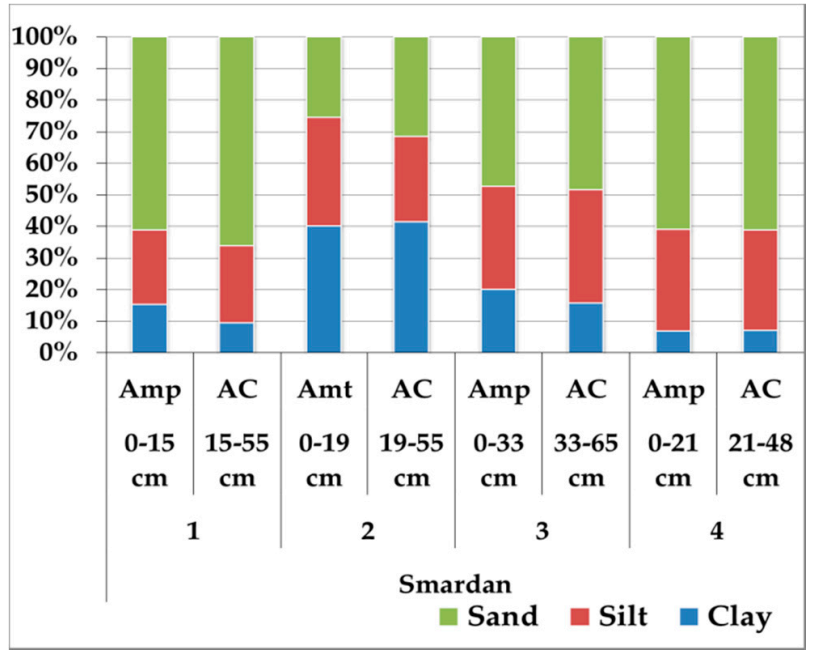

(a)

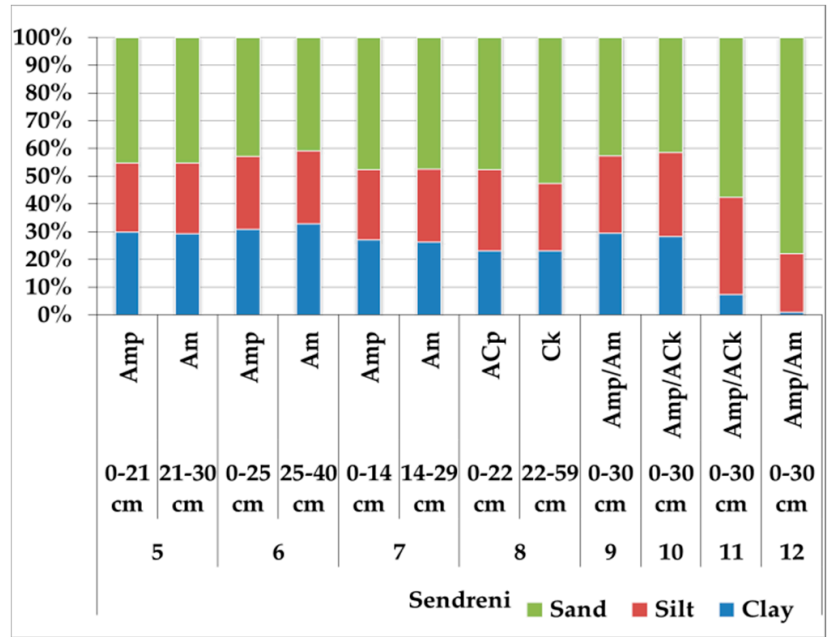

(b)

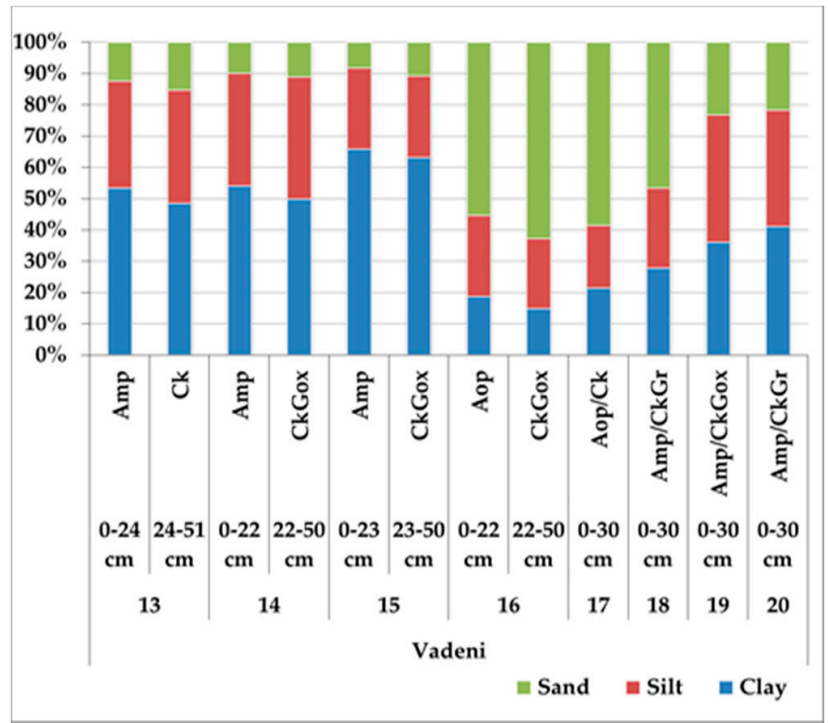

(c)

Figure 4. Soil granulometric fractions: (a) Smardan, (b) Sendreni, and (c) Vadeni areas. 
Studied soils have textures ranging from medium (loamy, loamy-sand) to fine (clay, loamy-clay) and coarse (sandy-loam) class.

On Smardan territory, the soils fall into the medium texture classes (profile 3, Am layer of profile 1), medium-fine (profile 2), and coarse (profile 4, and AC layer of profile 1). The soils in the Sendreni area have a medium texture, except sampling site no. 12, which is of coarse texture, while the Vadeni territory falls into the fine textural class, except for profile 16 , which has a medium texture, and sampling site no. 20, with medium-fine texture.

Recent studies carried out in the same region highlighted the connection between soil texture and its mineralogical composition $[62,63]$. According to this research, the soils in the Galati-Braila area consist of montmorillonite, kaolinite (clay minerals class), quartz, and calcite (non-clay minerals class). These minerals behave differently in different humidity conditions and influence the circulation of water and nutrients into the soil. In addition, clay minerals influence the rate of OM decomposition, physical properties, and the soil's chemical reactions [64].

\subsubsection{Soil Compaction}

Soil compaction is a characteristic closely related to a number of other physical soil parameters as follows: Particle size composition, bulk density, and total porosity, the values of which are given in Table 4.

Table 4. Soil physical indices of upper horizons.

\begin{tabular}{|c|c|c|c|c|c|c|}
\hline Sample Site & Horizon & $\begin{array}{c}\text { Depth } \\
(\mathrm{cm})\end{array}$ & $\begin{array}{c}\text { BD } \\
\left(\mathrm{g} \cdot \mathrm{cm}^{-3}\right)\end{array}$ & $\begin{array}{c}\text { TP } \\
(\%, v / v)\end{array}$ & $\begin{array}{c}\text { CR } \\
(\%, v / v)\end{array}$ & $\begin{array}{c}\mathbf{A P} \\
(\%, v / v)\end{array}$ \\
\hline \multicolumn{7}{|c|}{ Smardan } \\
\hline \multirow{2}{*}{1} & Amp & $0-15$ & 1.28 & 52 & -10 & 23 \\
\hline & $\mathrm{AC}$ & $15-55$ & 0.78 & 71 & -53 & 56 \\
\hline \multirow{2}{*}{2} & Amt & 0-19 & 1.00 & 63 & -22 & 32 \\
\hline & $\mathrm{AC}$ & $19-55$ & 1.08 & 60 & -16 & 29 \\
\hline \multirow{2}{*}{3} & Amp & $0-33$ & 1.45 & 46 & 4 & 13 \\
\hline & $\mathrm{AC}$ & $33-65$ & 1.34 & 50 & -6 & 20 \\
\hline \multirow{2}{*}{4} & Amp & $0-21$ & 1.24 & 54 & -17 & 30 \\
\hline & $\mathrm{AC}$ & $21-48$ & 1.12 & 59 & -27 & 37 \\
\hline \multicolumn{7}{|c|}{ Sendreni } \\
\hline \multirow{2}{*}{5} & Amp & $0-21$ & 1.11 & 59 & -17 & 29 \\
\hline & $\mathrm{Am}$ & $21-30$ & 1.25 & 53 & -7 & 20 \\
\hline \multirow[b]{2}{*}{6} & Amp & $0-25$ & 1.16 & 57 & -13 & 26 \\
\hline & $\mathrm{Am}$ & $25-40$ & 1.22 & 54 & -8 & 21 \\
\hline \multirow{2}{*}{7} & Amp & $0-14$ & 1.14 & 57 & -19 & 29 \\
\hline & $\mathrm{Am}$ & $14-29$ & 1.37 & 49 & -2 & 17 \\
\hline \multirow{2}{*}{8} & $\mathrm{ACp}$ & $0-22$ & 1.17 & 56 & -16 & 26 \\
\hline & Ck & $22-59$ & 1.32 & 51 & -5 & 20 \\
\hline 9 & Amp/Am & $0-30$ & 0.91 & 66 & -33 & 41 \\
\hline 10 & Amp/ACk & $0-30$ & 0.82 & 69 & -40 & 47 \\
\hline 11 & Amp/ACk & $0-30$ & 1.21 & 55 & -19 & 31 \\
\hline 12 & Amp/Am & $0-30$ & 1.26 & 53 & -18 & 35 \\
\hline \multicolumn{7}{|c|}{ Vadeni } \\
\hline \multirow{2}{*}{13} & Amp & $0-24$ & 1.32 & 51 & 6 & 12 \\
\hline & $\mathrm{Ck}^{\mathrm{I}}$ & $24-51$ & 1.22 & 55 & -4 & 19 \\
\hline \multirow{2}{*}{14} & Amp & $0-22$ & 1.40 & 48 & 11 & 8 \\
\hline & CkGox & $22-50$ & 1.38 & 49 & 9 & 10 \\
\hline \multirow{2}{*}{15} & Amp & $0-23$ & 1.11 & 59 & -5 & 17 \\
\hline & CkGox & $23-50$ & 1.08 & 60 & -8 & 21 \\
\hline \multirow{2}{*}{16} & Aop & $0-22$ & 1.34 & 50 & -4 & 20 \\
\hline & CkGox & $22-50$ & 1.30 & 52 & -9 & 25 \\
\hline 17 & Aop/Ck & $0-30$ & 1.05 & 61 & -26 & 35 \\
\hline 18 & Amp/CkGr & $0-30$ & 1.11 & 59 & -18 & 30 \\
\hline 19 & Amp/CkGox & $0-30$ & 0.91 & 66 & -30 & 39 \\
\hline 20 & Amp/CkGr & $0-30$ & 0.91 & 66 & -28 & 38 \\
\hline
\end{tabular}


Considering the agrotechnical works applied on the cultivated lands, the BD of soils did not vary greatly, falling within the extremely low to low field, except for the samples taken from profile 3 (Smardan), second layers of Sendreni soils and Vadeni soils, where a slight-medium compaction of upper layers is observed. The reason may be the same depth application of the tilling for a certain period of time, the direct relation to soil particle size composition and soil moisture.

In the pasture area (profile 2), both 0-19 $\mathrm{cm}$ layer $(\mathrm{Am})$ and $19-55 \mathrm{~cm}$ layer $(\mathrm{AC})$ have an extremely low-very low BD. Failure to comply with the grazing calendar created the premise of triggering an accelerated erosion process, accompanied by elements of current geomorphological phenomena due to the destabilization of soil particles by removing grass vegetation, as a result of excessive grazing, and of organic matter mainly by water erosion (Figure $5 a, b$ ).

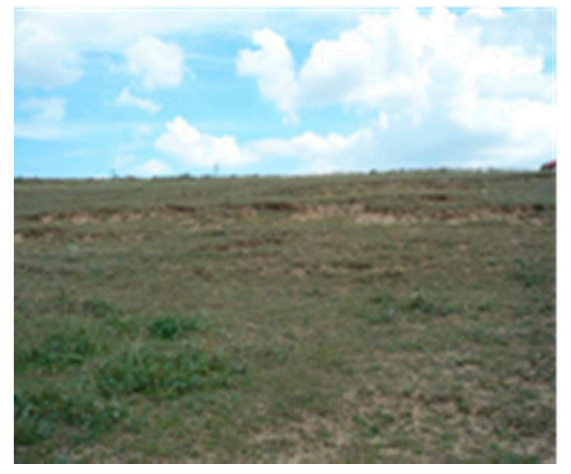

(a)

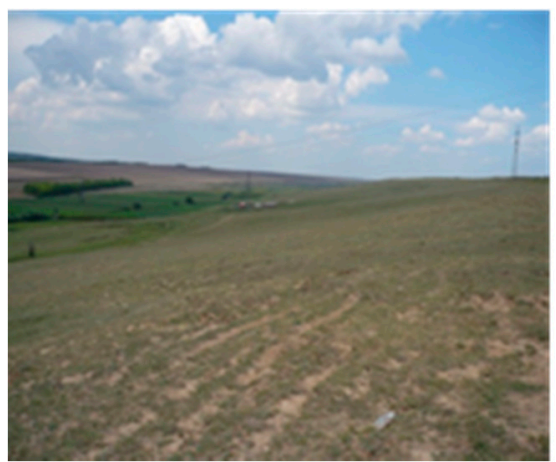

(b)

Figure 5. Pasture area soil erosion, Smardan area, due to: (a) Excessive grazing and (b) water erosion.

There is a strong relationship between texture, humus content, and BD. Overall, it is found that the upper horizons of the soil have low-extremely low BD values, which indicates a low degree of compaction, being within very loose-loose limits. Thus, in Smardan, BD is extremely low-low, ranging from $1.00-1.45 \mathrm{~g} \cdot \mathrm{cm}^{-3}$ in the Amp layer, and from $0.78-1.34 \mathrm{~g} \cdot \mathrm{cm}^{-3}$ in the AC layer. In Sendreni, BD values are lowest in the first layer (Amp, ACp), being between 1.11-1.17 $\mathrm{g} \cdot \mathrm{cm}^{-3}$ (extremely low-very low), while the second layer $(\mathrm{Am}, \mathrm{Ck}$ ) records values of $1.22-1.37 \mathrm{~g} \cdot \mathrm{cm}^{-3}$ (very low-low). The $0-30 \mathrm{~cm}$ layer (Amp/Am and Amp/ACk) is $0.82-1.26 \mathrm{~g} \cdot \mathrm{cm}^{-3}$ (extremely low-very low).

Exceptions are the soils on the Vadeni territory, where the high clay content generated higher values of $\mathrm{BD}$, ranging between 1.11-1.40 $\mathrm{g} \cdot \mathrm{cm}^{-3}$ (Amp, Aop) and 1.08-1.38 $\mathrm{g} \cdot \mathrm{cm}^{-3}$ (Ck, CkGox). Clay is known for its swelling properties in conditions of high humidity and shrinkage during drier periods [65]. In dry periods, it compacts, and cracks appear at the surface of the soil, some of them reaching even up to $30-50 \mathrm{~m}$ depth (Figure $6 \mathrm{a}-\mathrm{c}$ ). This requires special soil processing measures to restore aero-hydric conditions and facilitate the flow of nutrients in the soil-plant system. Samples from $0-30 \mathrm{~cm}$, which are of medium and medium-fine texture, show an extremely low $\mathrm{BD}$, ranging between $0.91-1.11 \mathrm{~g} \cdot \mathrm{cm}^{-3}$.

The friable texture of the soils in Smardan and Sendreni, cumulated with the low concentration of humus, as well as the agricultural works, contributed to the degradation of the upper horizons structure, which are slightly-moderately affected by water erosion (Figure 7a,b). In recent decades, this phenomenon has intensified due to changes in the frequency and intensity of rainfall and wind. 


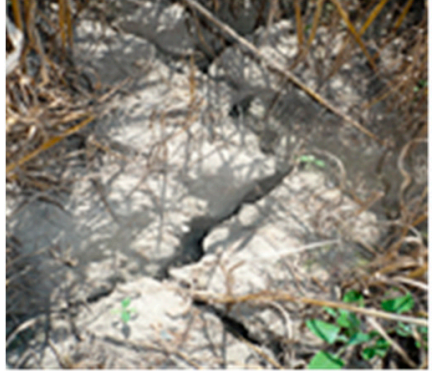

(a)

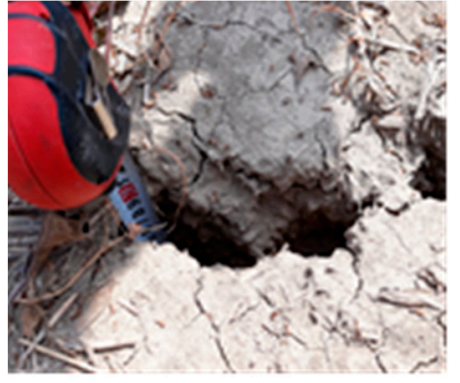

(b)

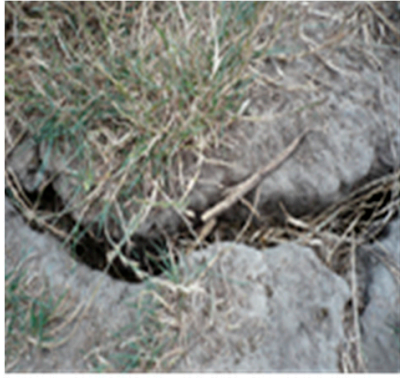

(c)

Figure 6. Summer season drought stress upon agricultural soils: (a) Sendreni, (b) Vadeni, and (c) Smardan areas.

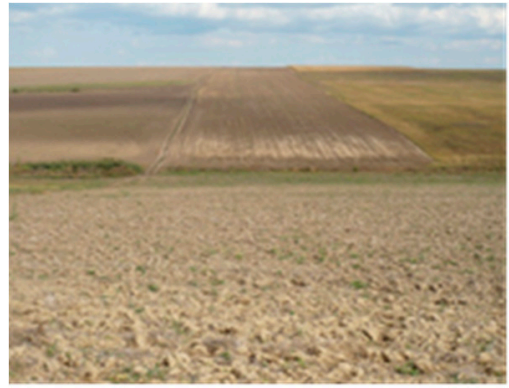

(a)

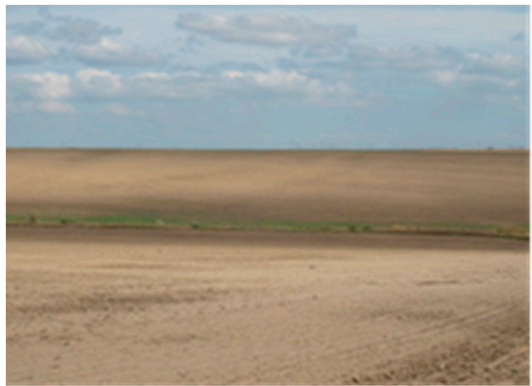

(b)

Figure 7. Soil erosion: (a) Valul lui Traian Hill, Sendreni area; (b) Rusca Mica Hill, Sendreni area.

BD values are inversely proportional to those obtained for TP. Chernozems of Smardan territory have a TP extremely high-high, in surface horizon Amp ranging between 46-63\%, while in the underlying horizon AC, TP is 50-71\% (extremely high-high). Chernozems on the Sendreni territory show similar values. Thus, the Amp and ACp horizons have a TP of 56-59\% (extremely high-very high), and the underlying horizon Am and Ck register values of 49-54\% (high-very high). The layer of $30 \mathrm{~cm}$ has a very high-extremely high TP, which records values of 53-66\%. In relation to BD, TP of the alluvial soils on Vadeni territory, is situated between the low-high limits in Amp and Aop horizons (48-59\%) and very high-low limits, in Ck and CkGox horizons (49-60\%). The 0-30 cm layer shows an extremely high TP (59-66\%).

In direct connection with $\mathrm{BD}$, soil texture, and $\mathrm{TP}$, it is observed that, generally, $\mathrm{AP}$ has values from low to very high in medium-textured soils, and from very low to high in fine-textured soils. Due to the low apparent density, on the extra-fine sandy loam texture, AP values are low in Amp horizon $(13 \%)$, and medium in AC horizon (20\%) in the CZ ka (profile 3), from Smardan. Clay soils from Vadeni (profiles 13,14,15), because of the high concentration of fractions with a diameter $<0.002 \mathrm{~mm}$ (48.54-65.91\% colloidal clay), have a low volume of air-filled pores, AP registering values of 8-19\% (very low-medium) in soils with medium-high BD (profiles 13 and 14), and 17-33\% (medium-very high), in horizons with low BD (profile 15). Both in Sendreni and Vadeni areas, the samples taken from the $0-30 \mathrm{~cm}$ layer have a high-very high AP (31-47\% in Sendreni; $30-39 \%$ in Vadeni).

Moreover, $\mathrm{CR}$ is correlated with the mentioned indices. The highest values are characteristic of soils with fine textures (profile 13,14,15), medium-high BD and low-medium TP, respectively. These soils are non-compacted (CR, -4 to $-5 \%$ ), slightly compacted (CR, 6 to $9 \%$ ), and moderately compacted (CR, 11\%). Soils with medium textures (profile 1, 2, 3, 4, 5, 6, 7, 8, 16, and sample sites no. $9,10,11,12,17,18,19,20)$, extremely low-low $\mathrm{BD}$ and high-extremely high $\mathrm{TP}$, are very loosened (CR, -4 to $-53 \%)$, loosened ( -13 to $-17 \%)$, and non-compacted (CR, -2 to $-8 \%)$. 


\subsection{The Main Hydro-Physical Parameters of Soils}

Table 5 shows the main hydro-physical soil indices of soil upper layers. In relation to BD, OM, and the percentage of colloidal clay in the soil, presented in Tables 3 and 4, it was found that as the percentage of clay increases, so does the capacity of the soil to retain water for a longer period of time, assimilated to FWC values, and also WC values. Therefore, loamy sand (AC layer of profile 1, Amp and AC layers of profile 3) and sand horizons (site no. 12) register a low level of FWC (14.34-19.81\%) and a very low level of WC (0.42-3.32\%), sandy loam horizons (Am layer of profile 1, Am and AC layer of profile 2 and Aop and CkGox layers of profile 16) have medium (21.61-22.88\%) FWC and low WC (5.22-7.04\%), while loam, silt, clay loam, and clay textured horizons (layers of profiles 2, 5, 6, 8, 13, 14, 15 , and sites no. $9,10,11,17,18,19,20)$ show medium $(22.96-24.79 \%)$, high $(25.75-30.18 \%)$, and very high $(30.80-38.16 \%)$ values of FWC. For the last soil category, WC is very low (2.61\%, site no. 11$)$, low $(6.72-8.16 \%$, profile $7,8,16)$, medium $(10.31-11.54 \%$, profile 5,6$)$, high (14.10-14.55\%, profile 2$)$, and very high $(17.04-23.12 \%$, profile $13,14,15)$.

Consequently, we conclude that the FWC and WC values, correlated with the clay percentage, increase in the order: Loamy sand $>$ sandy loam $>$ loam $>$ clay loam $>$ clay. [66] reported similar FWC values for soils formed on loessoid parent materials from Poland. Figure $8 \mathrm{a}-\mathrm{c}$ indicate the variation of the WC, FWC, and UWC indices on the three studied areas. In relation to BD and TP, TC falls into the high (31.93-39.89\%, profile 3, second layers of profiles 7 and 8, first layer of profiles 13 and 14), very high (40.81-55.56\%, most of the soils) and extremely high field (62.69-91.17\%, AC layer of profile 1 and Am layer of profile 2, sites no. 9, 10, 19, 20). Figure 9a-c shows the variation of TC on Smardan, Sendreni, and Vadeni areas. Depending on all the discussed parameters, DC of soils is within very low $(4.57 \%)$-very high $(71.65 \%)$ limits. It is found that soils with fine textures have a very low-medium drainage capacity (profiles 13,14,15), while soils with sandy and medium textures, generally, have a high-very high drainage capacity. DC variation on the two layers of soils are shown in Figure 10a-c.

In terms of EAWC level (Figure 11a-c), the low values $\left(493 \mathrm{~m}^{3} \cdot \mathrm{ha}^{-1}\right.$, Am layer of profile 14) indicate an increase in plant sensitivity to drought, which requires the application of irrigation works, in watering norms adapted to the soil texture and the requirements of the cultivated plants. Medium values are found in clayey and loam-clayey soils (profiles 3, 13, 14, 15), with EAWC ranging between 503-668 $\mathrm{m}^{3} \cdot \mathrm{ha}^{-1}$. High and very high values $\left(733-1117 \mathrm{~m}^{3} \cdot \mathrm{ha}^{-1}\right)$ are specific to loamy, sandy-loamy and sandy soils (Am layer of profile 1, profiles 3, 5, 6, 7, and 8; sites 9, 10,11, 12, 17, 18) and loam-clayey horizons of sites 19 and 20. $\left(757-805 \mathrm{~m}^{3} \cdot \mathrm{ha}^{-1}\right)$. 
Table 5. Hydro-physical parameters of soil upper horizons. WC: Wilting coefficient; FWC: Field water capacity; UWC: Useful water capacity; TC: Total capacity; DC: Draining capacity; EAWC: Easily accessible water capacity.

\begin{tabular}{|c|c|c|c|c|c|c|c|c|}
\hline $\begin{array}{c}\text { Sample } \\
\text { Site }\end{array}$ & Horizon & $\begin{array}{l}\text { Depth } \\
(\mathrm{cm})\end{array}$ & $\begin{array}{c}\text { WC } \\
(\%, w / w)\end{array}$ & $\begin{array}{c}\text { FWC } \\
(\%, w / w)\end{array}$ & $\begin{array}{c}\text { UWC } \\
(\%, w / w)\end{array}$ & $\begin{array}{c}\text { TC } \\
(\%, w / w)\end{array}$ & $\begin{array}{c}\text { DC } \\
(\%, \mathrm{~mm})\end{array}$ & $\begin{array}{c}\text { EAWC } \\
\left(\mathrm{m}^{3} \cdot \mathrm{ha}^{-1}\right)\end{array}$ \\
\hline \multicolumn{9}{|c|}{ Smardan } \\
\hline \multirow{2}{*}{1} & Amp & $0-015$ & 5.36 & 22.71 & 17.35 & 40.81 & 18.10 & 1110 \\
\hline & $\mathrm{AC}$ & $15-55$ & 3.32 & 19.52 & 16.20 & 91.17 & 71.65 & 505 \\
\hline \multirow{2}{*}{2} & Amt & 0-19 & 14.10 & 30.80 & 16.70 & 62.69 & 31.89 & 668 \\
\hline & $\mathrm{AC}$ & $19-55$ & 14.55 & 28.50 & 13.95 & 55.56 & 27.06 & 602 \\
\hline \multirow{2}{*}{3} & Amp & $0-33$ & 7.04 & 22.81 & 15.78 & 31.93 & 9.11 & 1144 \\
\hline & $\mathrm{AC}$ & $33-65$ & 5.51 & 22.88 & 17.37 & 37.59 & 14.71 & 1164 \\
\hline \multirow{2}{*}{4} & Amp & $0-21$ & 2.40 & 19.67 & 17.37 & 43.61 & 23.93 & 857 \\
\hline & $\mathrm{AC}$ & $21-48$ & 2.53 & 19.81 & 17.29 & 52.52 & 32.71 & 774 \\
\hline \multicolumn{9}{|c|}{ Sendreni } \\
\hline \multirow{2}{*}{5} & Amp & $0-21$ & 10.52 & 27.07 & 16.55 & 52.78 & 25.71 & 919 \\
\hline & $\mathrm{Am}$ & $21-30$ & 10.31 & 26.82 & 16.52 & 42.69 & 15.86 & 1032 \\
\hline \multirow{2}{*}{6} & Amp & $0-25$ & 10.84 & 26.81 & 15.97 & 48.89 & 22.08 & 926 \\
\hline & $\mathrm{Am}$ & $25-40$ & 11.54 & 27.31 & 15.77 & 44.65 & 17.34 & 962 \\
\hline \multirow{2}{*}{7} & Amp & $0-14$ & 7.37 & 24.79 & 17.42 & 50.41 & 25.62 & 993 \\
\hline & $\mathrm{Am}$ & $14-29$ & 6.72 & 22.96 & 16.24 & 35.68 & 12.72 & 1112 \\
\hline \multirow{2}{*}{8} & $\mathrm{ACp}$ & $0-22$ & 8.11 & 25.76 & 17.64 & 48.16 & 22.40 & 1032 \\
\hline & $\mathrm{Ck}$ & $22-59$ & 8.16 & 23.41 & 15.25 & 38.72 & 15.31 & 1007 \\
\hline 9 & Amp/Am & $0-30$ & 10.34 & 27.64 & 17.30 & 72.58 & 44.93 & 787 \\
\hline 10 & Amp/ACk & $0-30$ & 9.96 & 27.84 & 17.88 & 84.64 & 56.80 & 733 \\
\hline 11 & Amp/ACk & $0-30$ & 2.61 & 19.96 & 17.35 & 45.61 & 25.65 & 1050 \\
\hline 12 & Amp/Am & $0-30$ & 0.42 & 14.34 & 13.92 & 42.33 & 27.99 & 877 \\
\hline \multicolumn{9}{|c|}{ Vadeni } \\
\hline \multirow{2}{*}{13} & Amp & $0-24$ & 18.74 & 30.18 & 11.43 & 38.44 & 8.27 & 503 \\
\hline & $\mathrm{Ck}^{\mathrm{I}}$ & $24-51$ & 17.04 & 30.16 & 13.12 & 44.93 & 14.77 & 534 \\
\hline \multirow{2}{*}{14} & Amp & $0-22$ & 18.99 & 29.54 & 10.55 & 34.12 & 4.57 & 493 \\
\hline & CkGox & $22-50$ & 17.49 & 28.66 & 11.17 & 35.15 & 6.49 & 514 \\
\hline \multirow{2}{*}{15} & Amp & $0-23$ & 23.12 & 38.16 & 15.05 & 52.78 & 14.61 & 557 \\
\hline & CkGox & $23-50$ & 22.16 & 36.51 & 14.35 & 55.28 & 18.77 & 517 \\
\hline \multirow{2}{*}{16} & Aop & $0-22$ & 6.59 & 23.26 & 16.67 & 37.31 & 14.05 & 1117 \\
\hline & CkGox & $22-50$ & 5.22 & 21.64 & 16.42 & 39.89 & 18.25 & 1067 \\
\hline 17 & $\mathrm{Amp} / \mathrm{Ck}$ & $0-30$ & 7.51 & 24.41 & 16.90 & 58.20 & 33.79 & 887 \\
\hline 18 & Amp/CkGr & $0-30$ & 9.78 & 26.20 & 16.42 & 52.78 & 26.58 & 911 \\
\hline 19 & Amp/CkGox & $0-30$ & 12.66 & 30.37 & 17.70 & 72.85 & 42.49 & 805 \\
\hline 20 & Amp/CkGr & $0-30$ & 14.41 & 31.05 & 16.64 & 72.58 & 41.53 & 757 \\
\hline
\end{tabular}




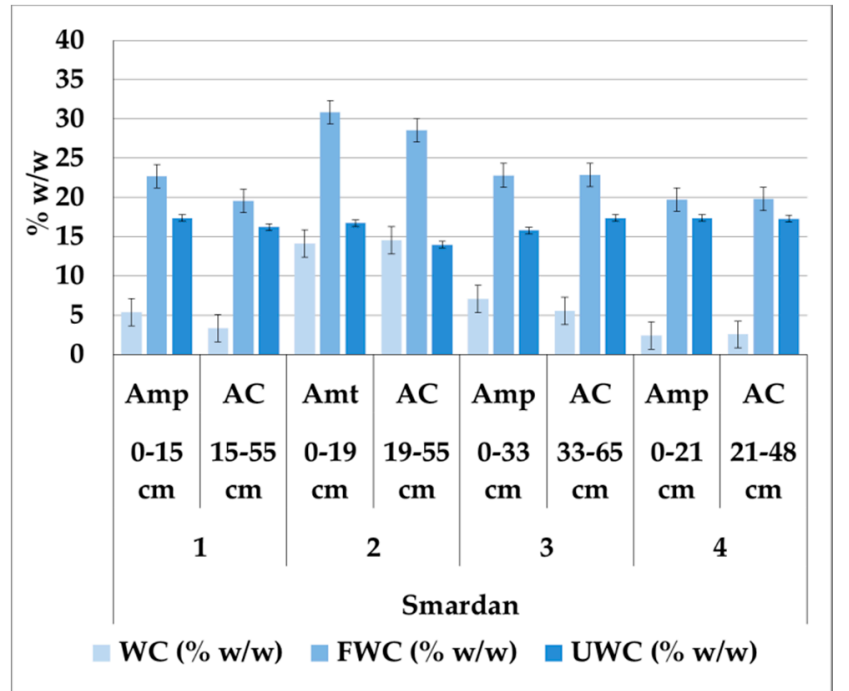

(a)

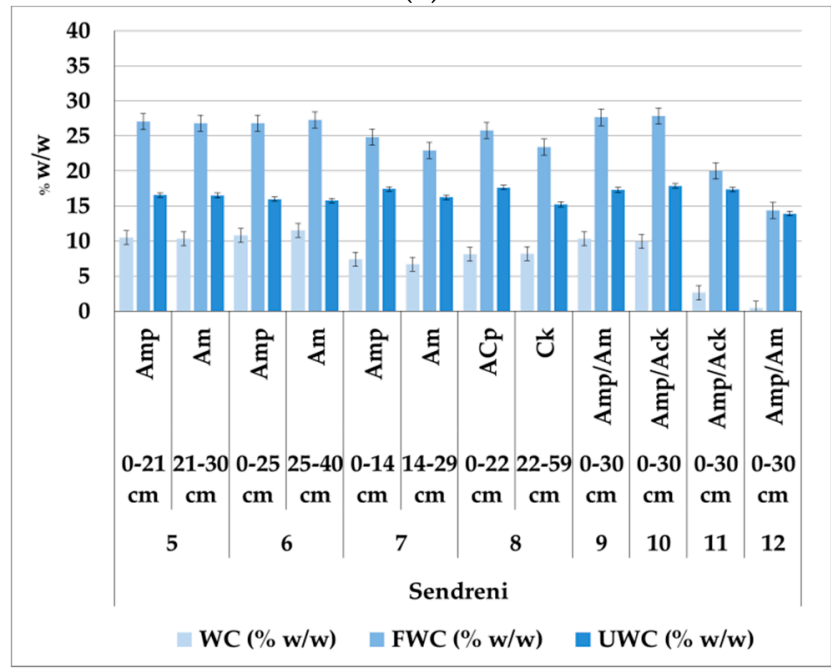

(b)

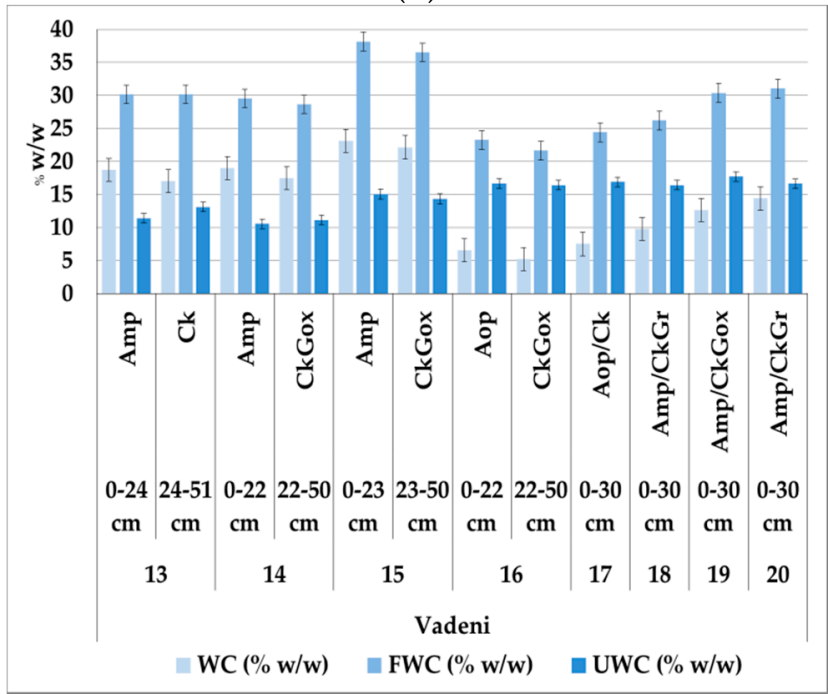

(c)

Figure 8. Agricultural soil's WC, FWC and UWC parameters: (a) Smardan, (b) Sendreni, and (c) Vadeni areas. 


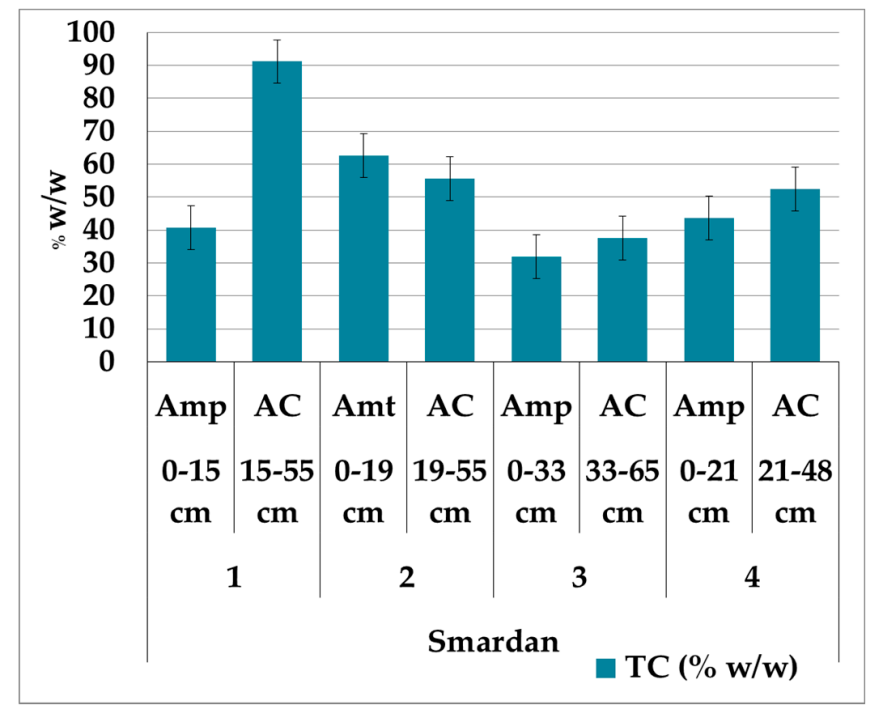

(a)

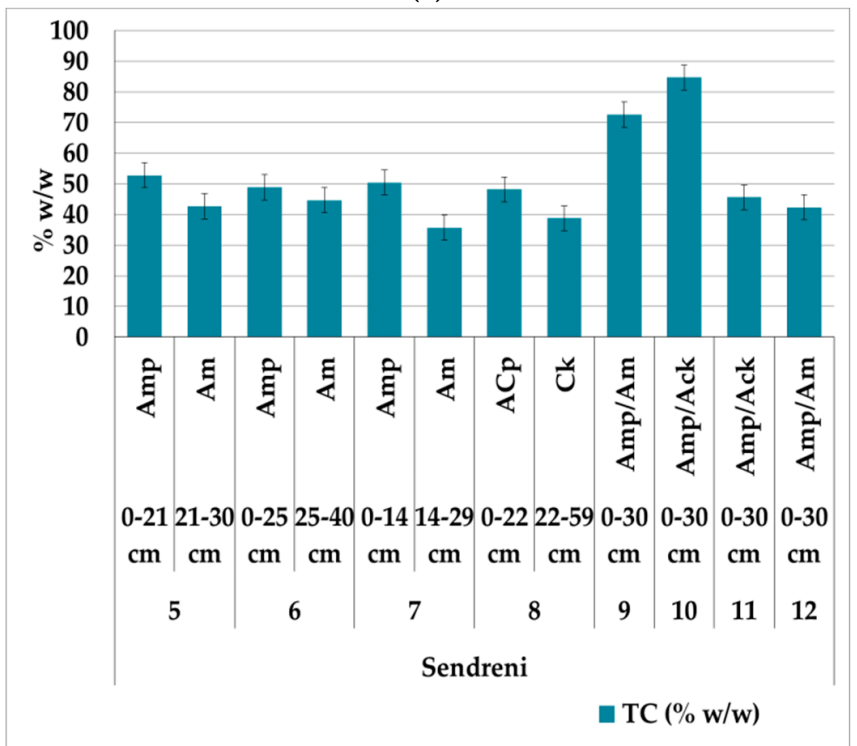

(b)

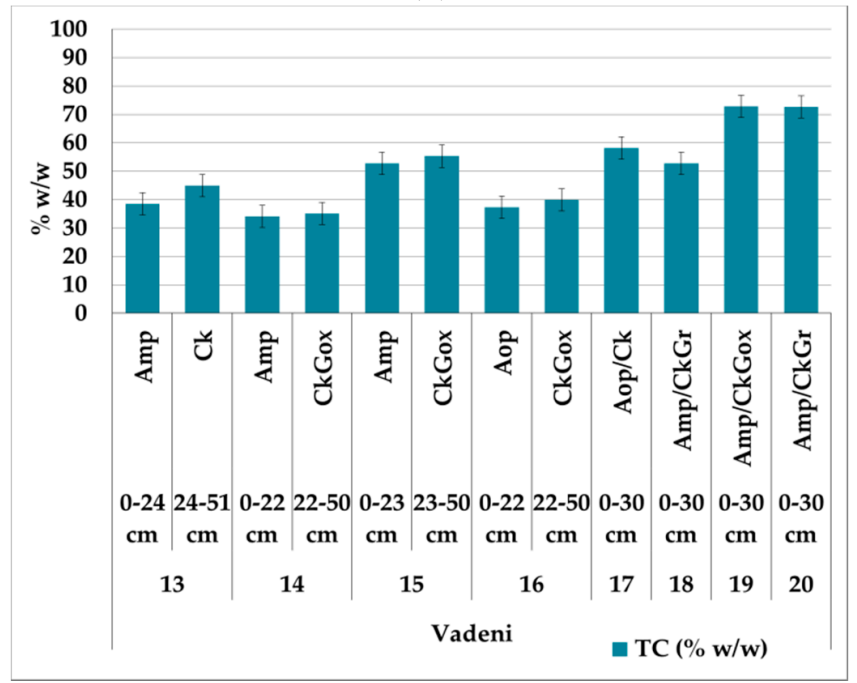

(c)

Figure 9. Total capacity variation in agricultural soils of: (a) Smardan, (b) Sendreni, and (c) Vadeni areas. 


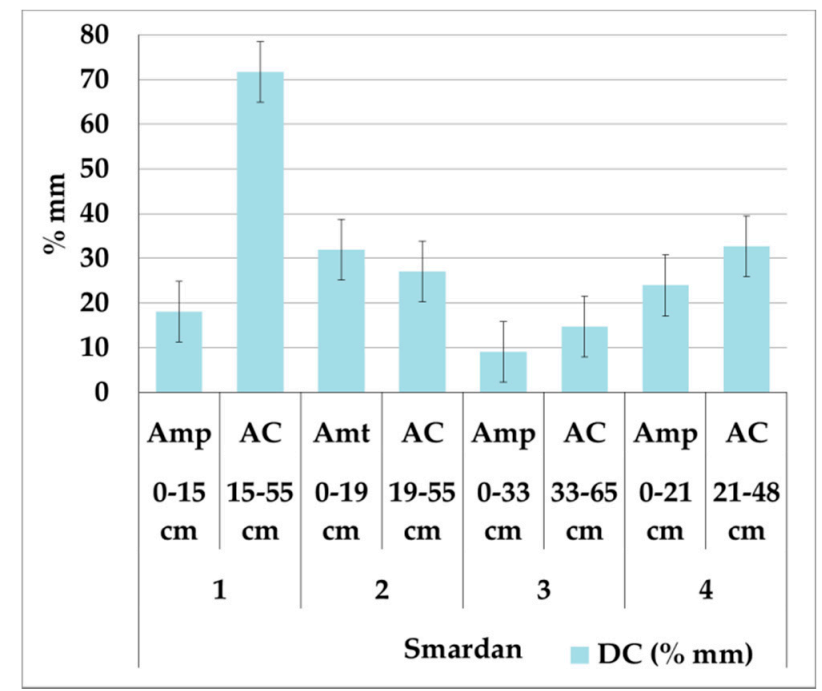

(a)

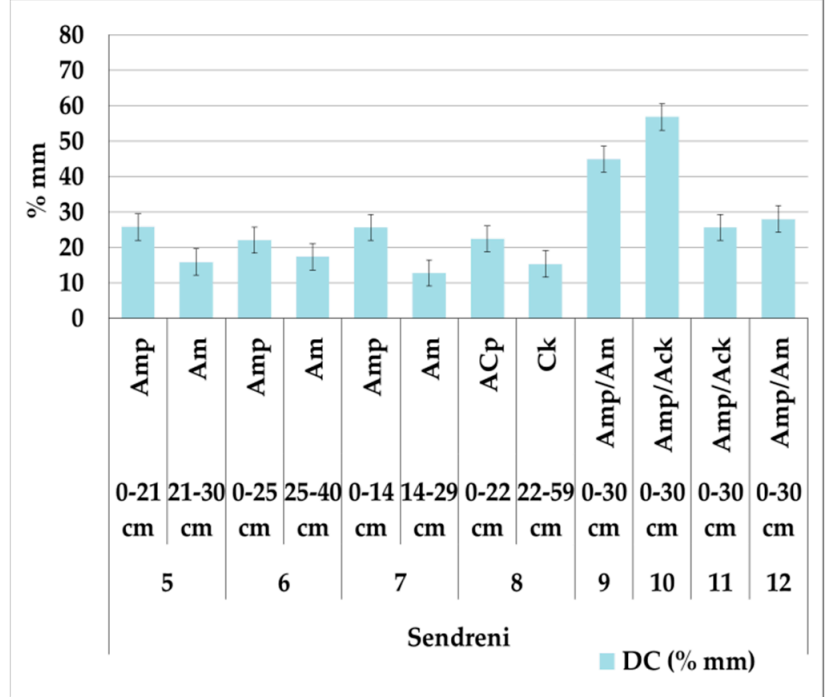

(b)

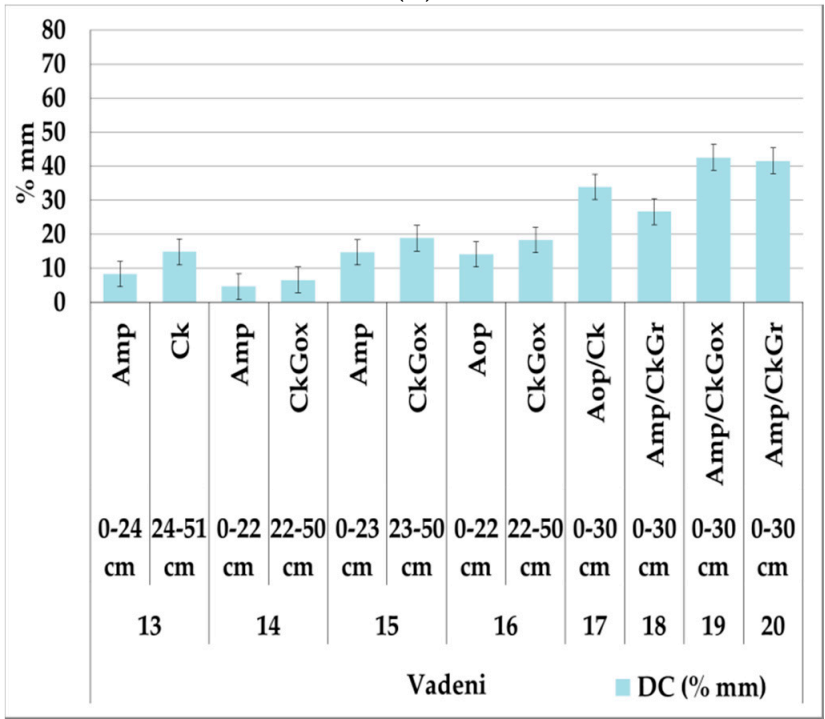

(c)

Figure 10. Drainage capacity variation in agricultural soils of: (a) Smardan, (b) Sendreni, and (c) Vadeni areas. 


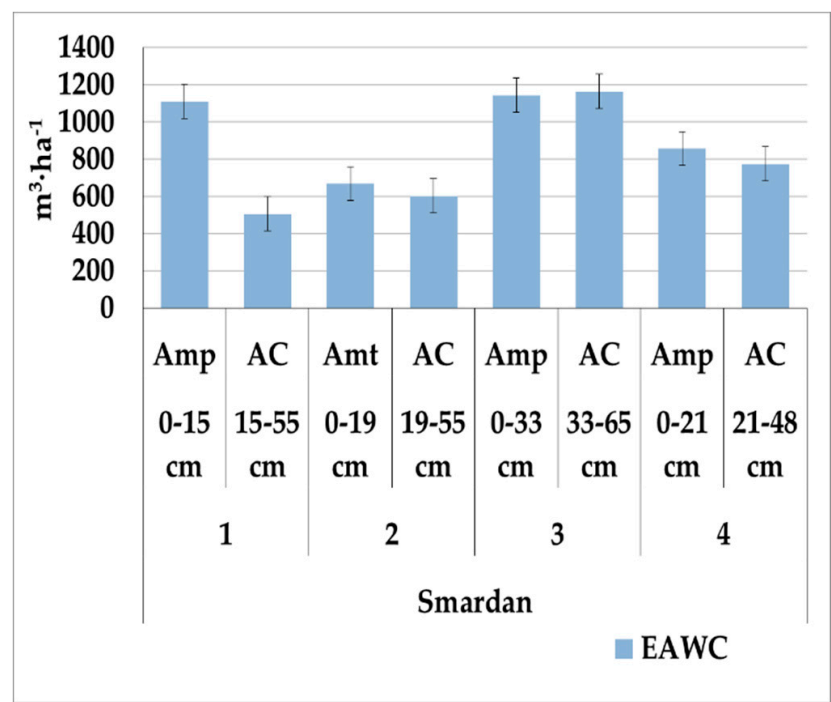

(a)

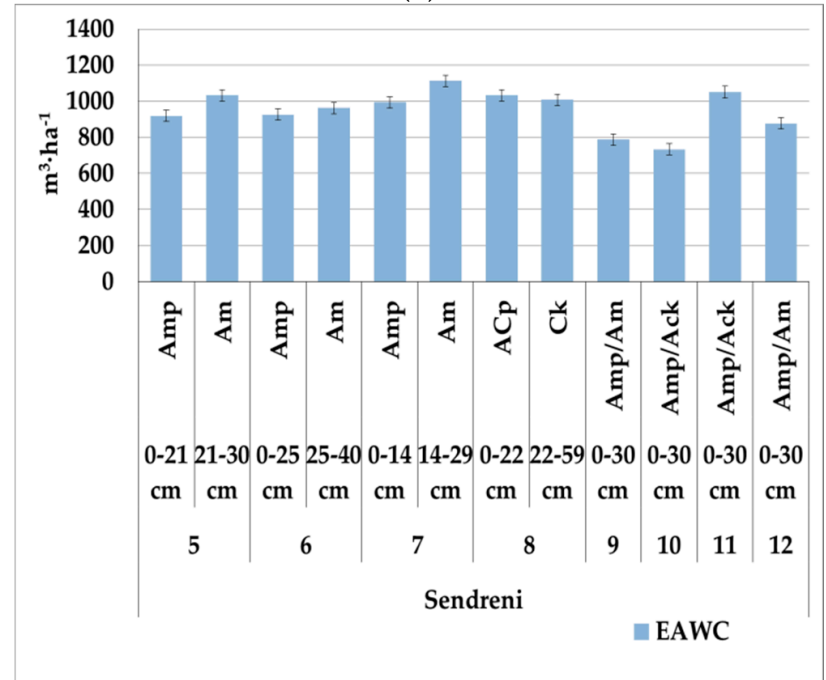

(b)

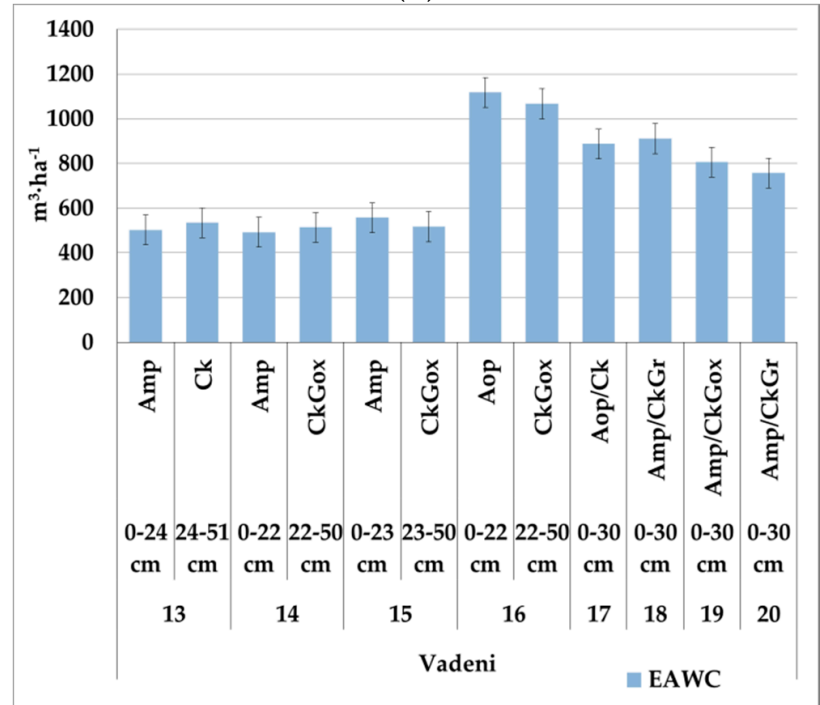

(c)

Figure 11. Easily available water capacity variation in agricultural soils of: (a) Smardan, (b) Sendreni, and (c) Vadeni areas. 


\section{Conclusions}

Soil evolution, in time and space, is directly influenced by the action of natural and anthropic factors. Global and local significant changes on the environment produce consequences that are often irreversible or difficult to control. One of these is the phenomenon of aridization, very prevalent in the southeastern part of Romania. In this context, we set out to research the main physical and hydro-physical parameters of soils. In order to assess soil parameters, twelve profiles were performed, and eight surface samples were collected on three territories located in the Danube basin in SE Romania. Among physical parameters, grain size and bulk density were determined, and total porosity, compaction rate, and aeration porosity were calculated. Additionally, the main hydro-physical parameters were calculated on the basis of specific formulas.

Generally, the results have highlighted that soils with coarse textures (loamy sand) have a reduced field water capacity. Soils with fine textures (clay loam, clay) may store a larger amount of water. They are considered wet, but unable to provide plants the water they need. By comparison, medium textures (sandy loam, loam), in correlation with bulk density, organic matter content, and colloidal clay percentage, have high and very high useful water capacity. As expected, FWC and WC values, correlated with the clay percentage, increase in the order: Loamy sand $>$ sandy loam $>$ loam $>$ clay loam > clay.

On the whole, the identified Chernozems have a high and very high draining capacity, correlated to granulometry. Exceptions are Fluvisols on Vadeni territory, which consists of high percentages of clay, making difficult profile drainage.

Hydro-physical indices results show the need for carrying out the irrigation works. In order to avoid soil degradation by secondary salinization, erosion, and/or leaching, farmers should be aware of compliance with irrigation rules, which must correspond to the physico-chemical characteristics of the soil, the specific crop, as well as local natural conditions. At the same time, specific agrotechnical measures are required to improve soil physical properties, so that the compaction of the upper horizons can be avoided. Tree planting protection is required on coarse texture soils for stabilization and reduction of the deflation phenomenon.

Our results suggested that the hydro-physical parameters of the soil are texture-, organic matterand fine fraction-dependent. Further thorough studies are necessary to assess soil water storage and availability for plants in the frame of climate change context. Stakeholders, policy makers, researchers, and non-governmental organizations should develop innovative strategies to combat drought, land degradation, and food scarcity in the near future.

Author Contributions: Conceptualization, S.-S.M. and A.E.; data curation, A.B.; formal analysis, A.B.; funding acquisition, A.E.; investigation, S.-S.M.; methodology, S.-S.M. and A.B.; project administration, A.E.; resources, A.E.; software, S.-S.M.; supervision, A.E.; validation, S.-S.M. and A.E.; writing-original draft, S.-S.M., A.E. and A.B.; writing-review and editing, S.-S.M. and A.E. All authors have read and agreed to the published version of the manuscript.

Funding: This research received no external funding.

Acknowledgments: The work was carried out in the frame of projects BSB27-MONITOX and BSB165-HydroEcoNex (2018-2021), Joint Operational Programme Black Sea Basin 2014-2020, and JINR-Romania project no. 71/2020. The work of PhD student Sorina-Simona Moraru has been funded by the European Social Fund through the Sectoral Operational Programme Human Capital 2014-2020, project Be Antreprenor!, Contract No. 51680/09.07.2019- SMIS code: 124539 . The authors are grateful to the County Soil Survey Offices of Galati and Braila for providing useful data. We also wish to thank the three anonymous reviewers for their thorough analysis of the manuscript and valuable comments which significantly contributed to the improvement of the paper quality.

Conflicts of Interest: The authors declare no conflict of interest.

\section{List of Abbreviations}

$\begin{array}{ll}\text { Abbreviation } & \text { Explanation } \\ \text { AM } & \text { Medium clay } \\ \text { AP } & \text { Aeration Porosity }\end{array}$




\begin{tabular}{|c|c|}
\hline $\mathrm{AP}$ & Silty clay \\
\hline AS & Fluvisols \\
\hline $\mathrm{BD}$ & Bulk Density \\
\hline $\mathrm{C}$ & Clay \\
\hline $\mathrm{CR}$ & Compaction Rate \\
\hline $\mathrm{CZ}$ & Chernozems \\
\hline CSSO & County Soil Survey Office \\
\hline $\mathrm{D}$ & Density \\
\hline DC & Draining Capacity \\
\hline EAWC & Easily Accessible Water Capacity \\
\hline FWC & Field Water Capacity \\
\hline GPS & Global Positioning System \\
\hline GS & Gleysols \\
\hline $\mathrm{H}$ & Soil Thickness \\
\hline LD & Layer Depth \\
\hline LL & Medium loam \\
\hline LP & Silty loam \\
\hline MNP & Minim Necessary Porosity \\
\hline NF & Fine sand \\
\hline $\mathrm{OM}$ & Organic Matter \\
\hline PN & Sandy silt \\
\hline Q & Soil particle $>2.0 \mathrm{~mm}$ diameter \\
\hline S & Silt \\
\hline SCI & Site of Community Importance \\
\hline SE & Extrafine sandy loam \\
\hline SF & Fine sandy loam \\
\hline SM & Medium sandy loam \\
\hline SPA & Special Protection Area \\
\hline TC & Total Capacity \\
\hline TP & Total Porosity \\
\hline TP & Silty clay loam \\
\hline TT & Medium clay loam \\
\hline UF & Fine loamy sand \\
\hline UWC & Useful Water Capacity \\
\hline WC & Wilting Coefficient \\
\hline
\end{tabular}

\section{References}

1. Bosello, F.; Roson, R.; Tol, R.S.J. Economy-wide estimates of the implications of climate change: Human health. Ecol. Econ. 2006, 58, 579-591. [CrossRef]

2. Ray, D.K.; West, C.P.; Clark, M.; Gerber, J.S.; Prishchepov, A.V.; Chatterjee, S. Climate change has likely already affected global food production. PLOS ONE 2019, 14, e0217148. [CrossRef] [PubMed]

3. Molua, E.L.; Lambi, M.C. The Economic Impact of Climate Change on Agriculture in Cameroon. World Bank Policy Res. Work. Pap. 2007, 4364. Available online: https://ssrn.com/abstract $=1016260$ (accessed on 4 August 2020).

4. Daba, M.H.; Bazi, Z.; Belay, A. Effects of Climate Change on Soil and Water Resources: A Review. Environ. Earth Sci. 2018, 8, 71-80.

5. Ummennhofer, C.C.; Meehl, G.A. Extreme weather and climate events with ecological relevance: A review. Philos. Trans. R. Soc. Lond. B Biol. Sci. 2017, 372, 1723. [CrossRef] [PubMed]

6. Cotago, A.; Meggio, F.; de Antoni Migliorante, M.; Marinello, F. Extreme Weather Events in Agriculture: A Systematic Review. Sustainability 2019, 11, 2547. [CrossRef]

7. del Pozo, A.; Brunel-Saldias, N.; Engler, A.; Ortega-Farias, S.; Acevedo-Opazo, C.; Lobos, G.A.; Jara-Rojas, R.; Molina-Montenegro, M.A. Climate Change Impacts and Adaptation Strategies of Agriculture in Mediterranean-Climate Regions (MCRs). Sustainability 2019, 11, 2769. [CrossRef] 
8. Mihai, B.; Reynard, E.; Werren, G.; Savulescu, I.; Sandric, I.; Chitu, Z. Impacts of tourism on geomorphological processes in the Bucegi Mountains in Romania. Geogr. Helv. 2009, 64, 134-147. [CrossRef]

9. Chan, C.S.; Nozu, K.; Zhou, Q. Tourism Stakeholder Perspective for Disaster-Management Process and Resilience: The Case of the 2018 Hokkaido Eastern Iuburi Earthquake in Japan. Sustainability 2020, 12, 7882. [CrossRef]

10. Mutana, S.; Mukwada, G. Mountain-route tourism and sustainability. A discourse analysis of literature and possible future research. J. Outdoor Recreat. Tour. 2018, 24, 59-65. [CrossRef]

11. Debiki, R.; Bilakowska, K.; Chodorowski, J.; Bartmiński, P. Impact of Tourism on Selected Properties of Soils of Bukowa Góra Educational Path. Ann. Univ. Mariae Curie-Skłodowska Lublin-Pol. 2014, LXIX, 69-77. [CrossRef]

12. Olya, H.G.T.; Shahmirzdi, E.K.; Alipour, H. Pro-tourism and anti-tourism community groups at a world heritage site in Turkey. Curr. Issues Tour. 2017, 22, 763-785. [CrossRef]

13. Kuby, M.J.; Wentz, E.A.; Vogt, B.J. Experiences in developing a tourism web site for hiking Arizona's highest summits and deepest canyons. Tour. Geogr. 2014, 3, 454-473. [CrossRef]

14. Kopittke, P.M.; Menzies, N.W.; Wang, P.; McKenna, B.A.; Lombi, E. Soil and the intensification of agriculture for global food security. Environ. Int. 2019, 132, 105078. [CrossRef] [PubMed]

15. Lal, R. Climate Change and Soil Degradation Mitigation by Sustainable Management of Soils and Other Natural Resources. Agric. Res. 2012, 1, 199-212. [CrossRef]

16. Rawls, W.J.; Gish, T.J.; Brakensiek, D.L. Estimating soil water retention from soil physical properties and characteristics. In Advances in Soil Science; Stewart, B.A., Ed.; Springer: New York, NY, USA, 1991; Volume 16, pp. 213-234. [CrossRef]

17. Moncada Mansonia, P.; Penning Letiane, H.; Timm, L.C.; Gabriels, D.; Cornelis Wim, M. Visual examinations and soil physical and hydraulic properties for assessing soil structural quality of soils with contrasting textures and land uses. Soil Tillage Res. 2014, 140, 20-28. [CrossRef]

18. Pires Luiz, F.; Borges Jaqueline, A.R.; Rosa Jadir, A.; Cooper, M.; Heck, R.J.; Passoni, S.; Roque, W.L. Soil structure changes induced by tillage systems. Soil Tillage Res. 2017, 165, 66-79. [CrossRef]

19. Rabot, E.; Wiesmeier, M.; Schlüter, S.; Vogel, H.J. Soil structure as an indicator of soil functions: A review. Geoderma 2018, 314, 122-137. [CrossRef]

20. Montgomery, D.R. Soil erosion and agricultural sustainability. Proc. Natl. Acad. Sci. USA 2007, 104, 13268-13272. [CrossRef] [PubMed]

21. Zaimes, G.N.; Tufekcioglu, M.; Schultz, R.C. Riparian land-use impact on stream bank and gully erosion in agricultural watersheds: What we have learned. Water 2019, 11, 1343. [CrossRef]

22. Foucher, A.; Salvador-Blanes, S.; Evrard, O.; Simonnesu, A.; Chapron, E.; Courp, T.; Cerdan, O.; Lefèvre, I.; Adriaensen, H.; Lecompte, F.; et al. Increase in soil erosion after agricultural intensification: Evidence from a lowland basin in France. Anthropocene 2015, 7, 30-41. [CrossRef]

23. Roesch, A.; Weisskopf, P.; Oberholzer, H.; Valsangiacomo, A.; Nemecek, T. An Approach for Describing the Effects of Grazing on Soil Quality in Life-Cycle Assessment. Sustainability 2019, 11, 4870. [CrossRef]

24. Rosales, M.; Livinets, S. Grazing and Land Degradation in CIS Countries and Mongolia. FAO, Livestock, Environment and Development Initiative (LEAD), Animal Production and Health Division. Available online: http://www.fao.org/fileadmin/templates/lead/pdf/e-conf_05-06_background.pdf (accessed on 15 October 2020).

25. Fijałkowski, K.; Kacprzak, M.; Grobelak, A.; Placek, A. The influence of selected soil parameters on the mobility of heavy metals in soils. Inżynieria Ochr. Środowiska 2012, 15, 81-92.

26. Rieuwerts, J.S.; Thorton, I.; Farago, M.E.; Ashmore, M.R. Factors influencing metal bioavailability in soils: Preliminary investigations for the development of a critical loads for metals. Chem. Spec. Bioavailab. 2015, 10, 60-75. [CrossRef]

27. Ramachela, K. Edaphic and climatic factors and the nutrient dynamics in Uapaca Kirkiana dominated miombo woodland agroforestry ecosystems. Agrofor. Syst. 2019, 93, 1501-1511. [CrossRef]

28. Letey, J. Relationship between soil physical properties and crop production. In Advances in Soil Science; Stewart, B.A., Ed.; Springer: New York, NY, USA, 1985; Volume 1, pp. 277-294. [CrossRef]

29. Horn, R.; Domżżał, H.; Słowińska-Jurkiewicz, A.; van Ouwerkerk, C. Soil compaction processes and their effects on the structure of the arable soils and the environment. Soil Tillage Res. 1995, 35, 23-36. [CrossRef] 
30. Brogowski, Z.; Kwasowski, W.; Madyniak, R. Calculating particle density, bulk density, and total porosity of soil based on its texture. Soil Sci. Annu. 2015, 65, 139-149. [CrossRef]

31. Ferré, T.P.A.; Warrick, A.W. Infiltration. Encycl. Soils Environ. 2005, 254-260. [CrossRef]

32. Omene, M.E.; Chokor, J.U.; Eyankware, M.O. The effects of land use on soil physicochemical properties within and around Ughelli, Nigeria. Int. J. Res. Rev. 2015, 2, 656-671. Available online: https://www. ijrrjournal.com/IJRR_Vol.2_Issue11_Nov2015/IJRR0115.pdf (accessed on 25 July 2020).

33. Loganathan, M.; Narendiran, J.N. Characterization of soil quality indicators: A study. J. Glob. Biosci. 2014, 3, 586-592. Available online: https://www.mutagens.co.in/jgb/vol.03/2/26.pdf (accessed on 25 July 2020).

34. Gajewski, P.; Kaczmarek, Z.; Owczarzak, W.; Mocek, A.; Glina, B. Selected physical and water properties of soils lacated in the vicinity of proposed opencast lignite mine "Dezewce" (middle Poland). Soil Sci. Annu. 2015, 66, 75-81. [CrossRef]

35. Carter, M.R. Soil quality for sustainable land management: Organic matter and aggregation interactions that maintain soil function. Agron. J. 2002, 94, 38-47. [CrossRef]

36. Alvarez, A.M.; Carral, P.; Hernandez, Z.; Almendros, G. Assessment of soil organic matter mollecular characteristics related to hydrophysical properties in semiarid soils (Central Spain). Arid Land Res. Manag. 2014, 27, 303-326. [CrossRef]

37. Murphy, B.W. Impact of soil organic matter on soil properties - a review with emphasis on Australian soils. Soil Res. 2015, 53, 605-635. [CrossRef]

38. Rieder, A.; Madarasz, B.; Szabo, J.A.; Zachary, D.; Vancsik, A.; Ringer, M.; Szalai, Z.; Jakab, G. Soil organic matter alteration velocity due to land-use change: A case study under conservation agriculture. Sustainability 2018, 10, 943. [CrossRef]

39. Antoneli, V.; Mosele, A.C.; Bednarz, J.A.; Pulido-Fernandez, M.; Lozzano-Parra, J.; Keesstra, S.D.; Rodrigo-Comino, J. Effects of applying liquid swine manure on soil quality and yield production in tropical soybean crops (Parana, Brazil). Sustainability 2019, 11, 3898. [CrossRef]

40. Ene, A.; Bosneaga, A.; Georgescu, L. Determination of heavy metals in soils using XRF technique. Rom. J. Phys. 2010, 55, 815-820.

41. Ene, A.; Pantelica, A.; Freitas, M.C.; Bosneaga, A. EDXRF and INAA analysis of soils in the vicinity of a metallurgical plant. Rom. J. Phys. 2011, 56, 993-1000.

42. Ene, A.; Bogdevich, O.; Sion, A.; Spanos, T. Determination of polycyclic aromatic hydrocarbons by gas chromatography-mass spectrometry in soils from Southeastern Romania. Michrochem. J. 2012, 100, 36-41. [CrossRef]

43. Ene, A.; Bogdevich, O.; Sion, A. Levels of organochlorine pesticides (OCPs) and polycyclic aromatic hydrocarbons (PAHs) in topsoils from SE Romania. Sci. Total Environ. 2012, 439, 76-86. [CrossRef]

44. Arbanas, S.S.; Ene, A.; Moraru, D.I. Contamination level of Triticum vulgare L. cultivated on soils around a metallurgical area in Galati, Romania. Ann. Dunarea Univ. Galati Fascicle II Math. Phys. Theor. Mech. 2019, 42, 1-9. [CrossRef]

45. Ene, A.; Moraru, S.S.; Moraru, D.I. Assessment of bioaccumulation of heavy metals in sunflower cultivated in the agricultural area next to steel industry. In Proceedings of the 19th International Multidisciplinary Scientific Conference on Earth \& Planetary Science-SGEM Geoconference, 3.2-Soils, Water Ecosystems, Albena, Bulgaria, 30 June-6 July 2019; pp. 25-32. [CrossRef]

46. Kumar, A.; Cabral-Pinto, M.; Kumar, A.; Kumar, M.; Dinis, P.A. Estimation of risk to the eco-environment and human health of using heavy metals in the Uttarakhand Humalaya, India. Appl. Sci. 2020, 10, 7078. [CrossRef]

47. Bockel, L. Climate Change and Agricultural Policies. How to Mainstream Climate Change Adaption and Mitigation into Agricultural Policies. Food and Agriculture Organization of the United Nations (FAO) Policy Learning Programme. 2019. Available online: http://www.fao.org/docs/up/easypol/779/policy-clim_change_ 240en.pdf (accessed on 14 October 2020).

48. European Environment Agency. Climate Change Adaptation in the Agriculture Sector in Europe. EEA Report. 2019. Available online: https:/www.euroseeds.eu/app/uploads/2019/09/Climate-change-adaptation-in-theagriculture-sector-in-Europe.pdf (accessed on 15 October 2020).

49. European Commission. The CAP and Climate Change. Available online: https://ec.europa.eu/info/foodfarming-fisheries/sustainability/environmental-sustainability/climate-change_en\#capandclimatechange (accessed on 15 October 2020). 
50. Stanescu, I.; Swizewski, C.; Vacarasu, I.; Sficlea, V. Masivul Ceahlau, Tara Giurgeului, Depresiunea Darmanesti, Podisul Covurlui-Cercetari in geografia Romaniei; Editura Stiintifica si Enciclopedica: Bucuresti, Romania, 1980; pp. 227-236.

51. Cotet, P.V. Campia Romana—Studiu de Geomorfologie Integrate; Ceres: Bucuresti, Romania, 1976; p. 21.

52. Coldea, G.; Negrean, G.; Sarbu, I.; Sarbu, A. Ghid Pentru Identificarea si Inventarierea Pajistilor Seminaturale din ROMANIA; Alo: Bucuresti, Romania, 2001; pp. 18-20.

53. Florea, N.; Munteanu, I. Sistemul Roman de Taxonomie a Solurilor; Sitech: Craiova, Romania, 2012.

54. County Soil Survey Office of Galati. Pedological and Agrochemical Study in Order to Achieve and Update the County Soil-Land Monitoring System for Agriculture. Sendreni Communal Territory; County Soil Survey Office of Galati: Galati, Romania, 2014.

55. County Soil Survey Office of Galati. Pedological and Agrochemical Study in Order to Achieve and Update the County Soil-Land Monitoring System for Agriculture. Smardan Communal Territor; County Soil Survey Office of Galati: Galati, Romania, 2017. (In Romanian)

56. County Soil Survey Office of Braila. Pedological and Agrochemical Study in Order to Achieve and Update the County Soil-Land Monitoring System for Agriculture. Vadeni Communal Territory Village Territory; County Soil Survey Office of Braila: Braila, Romania, 2018. (In Romanian)

57. Dumitru, E.; Calciu, I.; Carabulea, V.; Canarache, A. Metode de Analiza Utilizate in Laboratorul de Fizica a Solului; Sitech: Craiova, Romania, 2009.

58. Dumitru, M.; Dumitru, S.; Tanase, V.; Mocanu, V.; Manea, A.; Vrânceanu, N.; Preda, M.; Eftene, M.; Ciobanu, C.; Calciu, I.; et al. Monitoringul Starii de Calitate a Solurilor din Romania; Sitech: Craiova, Romania, 2011.

59. Bot, A.; Benites, J. Natural factors influencing the amount of organic matter. In The Importance of Soil Organic Matter, FAO Soils Bulletin; Publishing Management Service Information Division FAO: Rome, Italy, 2005; Volume 80, p. 78. Available online: http://www.fao.org/3/a0100e/a0100e00.htm\#Contents (accessed on 2 August 2020).

60. Vasiliniuc, I. Hydeophysical indicators of the soils in Horoiata basin. PESD 2010, 4, 287-297.

61. Vlad, V.; Toti, M.; Florea, N.; Mocanu, V. Corelarea Sistemelor de Clasificare a Solurilor SRCS si SRTS-Sistemul SRTS+; Sitech: Craiova, Romania, 2014; p. 19.

62. Moraru, S.S.; Ene, A.; Gosav, S. Study of the correlativity between parameters and mineralogy of contaminated agricultural soils. In Proceedings of the 19th International Multidisciplinary Scientific Conference on Earth \& Planetary Science-SGEM Geoconference, 3.2-Soils, Water Ecosystems, Albena, Bulgaria, 30 June-6 July 2019; pp. 441-448. [CrossRef]

63. Moraru, S.S.; Ene, A.; Gosav, S. Mineralogical composition assessment of soils from Covurlui and Braila plains by ATR-FTIR technique. Proceedings 2019, 29, 80. [CrossRef]

64. Sarkar, B.; Singh, M.; Mandal, S.; Churchman, G.J.; Bolan, N.S. Chapter 3-Clay Minerals-Organic Matter Interactions in Relation to Carbon Stabilization in Soils. In The Future of Soil Carbon. Its Conservation and Formation; Garcia, C., Nannipieri, P., Hernandez, T., Eds.; Academic Press: London, UK, 2018; pp. 71-86. [CrossRef]

65. Tang, C.S.; Cui, Y.J.; Tang, A.M.; Shi, B. Experiment evidence on the temperature dependence of desiccation cracking behavior of clayey soils. Eng. Geol. 2010, 114, 261-266. [CrossRef]

66. Walczak, R.; Ostrowski, J.; Witkowska-Walczak, B.; Sławiński, C. Spatial characteristic of hydro-physical properties in arable mineral soils in Poland as illustrated by field water capacity (FWC). Int. Agrophys. 2002, 16, 151-159.

Publisher's Note: MDPI stays neutral with regard to jurisdictional claims in published maps and institutional affiliations.

(C) 2020 by the authors. Licensee MDPI, Basel, Switzerland. This article is an open access article distributed under the terms and conditions of the Creative Commons Attribution (CC BY) license (http://creativecommons.org/licenses/by/4.0/). 